\title{
From Rome to Nice in a Wheelchair, The Development of a European Disability Policy
}

Citation for published version (APA):

Waddington, L. B. (2005). From Rome to Nice in a Wheelchair, The Development of a European Disability Policy. Europa Law Publishing. https://doi.org/10.26481/spe.20050401lw

Document status and date:

Published: 01/04/2005

DOI:

10.26481/spe.20050401lw

Document Version:

Publisher's PDF, also known as Version of record

\section{Please check the document version of this publication:}

- A submitted manuscript is the version of the article upon submission and before peer-review. There can be important differences between the submitted version and the official published version of record.

People interested in the research are advised to contact the author for the final version of the publication, or visit the DOI to the publisher's website.

- The final author version and the galley proof are versions of the publication after peer review.

- The final published version features the final layout of the paper including the volume, issue and page numbers.

Link to publication

\footnotetext{
General rights rights.

- You may freely distribute the URL identifying the publication in the public portal. please follow below link for the End User Agreement:

www.umlib.nl/taverne-license

Take down policy

If you believe that this document breaches copyright please contact us at:

repository@maastrichtuniversity.nl

providing details and we will investigate your claim.
}

Copyright and moral rights for the publications made accessible in the public portal are retained by the authors and/or other copyright owners and it is a condition of accessing publications that users recognise and abide by the legal requirements associated with these

- Users may download and print one copy of any publication from the public portal for the purpose of private study or research.

- You may not further distribute the material or use it for any profit-making activity or commercial gain

If the publication is distributed under the terms of Article $25 \mathrm{fa}$ of the Dutch Copyright Act, indicated by the "Taverne" license above, 
From Rome to Nice in a Wheelchair 
7) Europa Law Publishing, Groningen 2006 


\section{From Rome to Nice in a Wheelchair}

The Development of a European Disability Policy

Lisa Waddington

Lecture

given in a shortened form on accepting the position of European Disability Forum Extraordinary Chair in European Disability Law at: Maastricht University on I April 2005 
Europa Law Publishing is a publishing company speciahzing in European Union law, intermational trade law, public international law, environmental law and comparative national law.

For further information please contact Europa Law Publishing wa email: infoge europalawpublishing com or wisit our wrelssite at: www.europallawpublishing.com.

All rights reserwed. No part of this publication may be reproduced of transmitted, in any form or by any means, or stored in any retrieval system of amy nature, without the written permission of the publisher. Application for permission for use of copyright material shall be made to the publishers. Full acknowledgement of author, publisher and source must be given.

Voor zover het maken van kopieèn uit deze uitgave is toegestaan op grond van artikel $\mathrm{s} 6 \mathrm{~h} \mathrm{t} / \mathrm{m} \mathrm{m} / \mathrm{m}$ Auteurswet 1912 juncto het Besluil wan 27 november 2002, Stb. 575 , dient men de daarwor wettelijk verschuldigde vergoedingen te voldoen an de Stichting Reprorecht (Postbus 3060, 2130 KB Hoofddorp). Voor het overnemen van (een) gedeelte (n) uit deze uitgave in bloemlezingen, readers en andere compilatiewerken (artikel 16 Auteurswet 1912) dient men zich tot de uitgever te wenden.

(c) Europa Law Publishing, L. Waddington, 2006

Typeset in Scalla and Scala Sans, Graphic design by Gak Designers, Groningen/Amsterdam

NUR 828

ISBN-10:90-76871-68-K

ISBN-13:978-90-76871-68.4

British Library Caltaloguing-ir-Publication Data

A catalogue record for this book is available from the British Library 
From Rome to Nice in a Wheelchair; The Development of a European Disability Policy

From Rome to Nice in a Wheelchair; The Development of a

European Disability Policy

I. European Community Disability Policy up until the mid 1990 s

A. Community Action Programmes in the Field of Disability - the HELIOS Initiatives

B. Policy Initiatives

C. Other Funding Programmes

D. General Community Policies Overlooking Disability - Some Examples

E. Reflection on the State of Play in the mid iggos

2. European Community Disability Policy, r995-1999

A. A Philosophical Change

B. The Inwolvement of Disabled People in Community Decision Making

3. European Disability Policy 1999 - Present Day

A. Changes introduced by the Amsterdam Treaty and the Adoption of the Framework Employment Directive

B. Mainstreaming Disability into General EU Policy and Legislation

C. Disability Specific Initiatives

D. The Nice Treaty and the EU Charter of Fundamental Rights

4. Looking to the Future

A. The EU Constitution

B. Combating Disability Discrimination and Promoting Equality 
From Rome to Nice in a Wheelchair The Development of a European Disability Policy 


\section{From Rome to Nice in a Wheelchair; The Development of a European Disability Policy}

Preparing an inaugural lecture, particularly one that seeks to give an overview of developments that have occurred over a number of yearis; has given me a good excuse to revisit some of my earlier work. Please forgive me therefore if I indulge myself by reflecting a little on my first piece of research on the topic of European disability law. In 1989 I had the pleasure to be admitted to the European University Institute in Florence, and, some 4 years later, on 6 December 1993, I successfully defended my Ph.D there. My Ph.D. bore the title More Disabled Than Others. The Employment of Disalled People within the European Community: An Analysis of Existing Measures and Proposals for Reform."

Wher 1 commenced my research in Florence in 1989 our wheelchair travel. ler of the title of this lecture, had already left Rome, where the original EEC Treaty was signed in $1957^{2}$ and travelled to Luxembourg, where that Treaty was amended for the first time by the Single European Act in 1987 . That journey had taken our traveller some 30 years. By the time 1 defended my Ph.D in 1993 our traveller had moved on to the Provinciehuis in Maastricht, where the Maastricht Treaty was signed. 4 "That journey had taken almost 5 years. 35 years had therefore passed since the Rome Treaty had been signed - time enough one would imagine to build up a substantial body of primary and secondary legislation and case law which amounted to a European Community disability policy.

\section{European Community Disability Policy up until the mid 1990 ${ }^{5}$}

There had undoubtedly been the time, but there was not the policy. In 993 one could identify a number of minor and disparate strands of EC policy that were directly targeted at disabled people. Unfortunately, there were also many examples of situations where the needs of disabled people had been completely overlooked, and where the application of the Treaty, and secondary legislation derived from the Treaty, had resulted in disadvantage and exclusion.

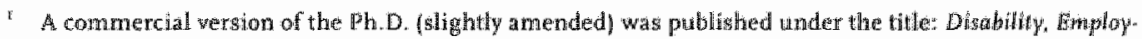
mem and the European Commuraty (London: Blackstonte, 1995 ).

2 The Rome Treaty was signed on 25 March 1957 and encered into force on Ianuary 1958 ,

3 The Single European Act was gigned on 77 and 28 February 2986 in Luxembourg and The Hegues, and entered into force on 1 luly $198 \%$

4 The Mastricht Treaty the Treaty Establighing the European Union was signed on 7 february 1992 and entered into force on 1 Nowember 1993 .

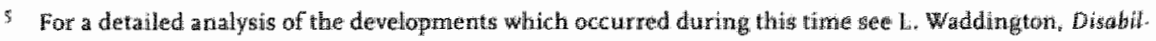

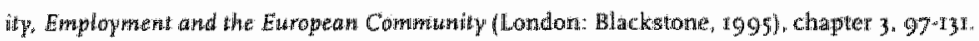


The Treaty in force in 1993, and indeed all the Pre-Amsterdam Treaties, contained no reference to disability. As a consequence it was very difficult for the Community institutions to develop any kind of disability policy during this period. The initiatives that were taken with regand to disability were primarily non-binding or took the form of action programmes providing for exchanges and information dissemination. The one policy proposal that took the form of binding legislation, concerning transport to work for disabled workers, failed to be adopled.

\section{A. Community Action Programmes in the Field of Disability - the HELIOS ${ }^{6}$ Initiatives}

Between 1974 and 1996 Community Action Programmes were the mainstay of European Community disability policy. This may seem strange to those who approach the topic from a national perspective, particularly when one becomes aware of the limited nature of many of these programmes. How ever, the fact that Action Programmes played such a significant part in the Corn. munity's response to disability reflects the limited legal competencies which the Community had in this area up until recently.

The Community established four multi-annual disability Action Programmes between 1974 and 1996.7 The object of these programmes was to promote the exchange of information and best practice, and to contribute to the dewelopment of a wider Community disability policy. The former objective was achieved through the establishment of warious European networks and exchange activities focusing on specific themes, the establishment of a computerised multilingual information system (Handynet), the distribution of newsletters, and the provision of funding for one-off conferences and meetings. The latter objective, relating to the development of a broader Community disability policy, was not achieved to any great degree. However, the later Action Programmes, Helios I (1988-1992) and Helios II (1993-1996), did actively encourage the development of disability Non-Governmental Organisations and established a formal consultation mechanism with such organisations. These points are examined in more detail below.

The Hellos II Programme was the last disability action programme of its generation. In 1996 , when the programme came up for renewal, it proved

6) Helos was an acrom mand stood for Handicapped People in the Europeary Community Living Independetetly in an open society.

7. Unitial Community Action Programme for the Vacational Rehabilitation of Handicapped Persons

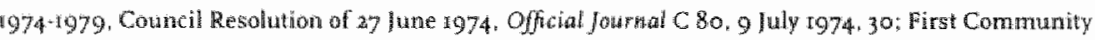
Action programme on the Social Integration of Handicapped People $1983-1988$. Offial Joumal C 347 .

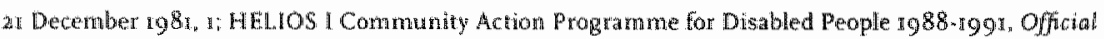
Jowmal L 104, 23 April rg 88, 38; HELLOS II Community Action Progranme to assist Disabled People

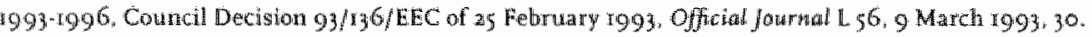


impossible to reach agreement within the Council on the continuation of this, and number of other social action programmes. The political climate has now changed, and, with the embracing of the principle of mainstreaming, it is unlikely that the Community would consider a programme of this nature. 2003 however saw the adoption of a new disability specific action programme which has a one of its key goals, perhaps paradoxically, the mainstreaning of disability issues.

\section{i. Information Dissemination: European Networks and Handynet}

The dissemination of information was one of the major objec. tives of the various Community Disability Action Programmes. This was to be achieved in a number of ways:

\section{a. European Networks}

All four Action Programmes provided for European networks examining specific themes. The early Programmes, in the ' 70 s and ' 80 s, focused exclusively on employment related issues, and provided for an network of rehabilitation centres and networks focusing on wocational training and economic integration. In contrast, the networks established under the two later Helios Programmes covered a far broader area, addressing not only economic and vocational integration, but also social integration and independent living. This expansion reflected a development in the Community's thinking on disability, and the recognition of the need for a more holistic approach.

The networks encouraged the exchange of information through study visits and conferences, with the ultimate aim of spreading good practice both within the network itself, and beyond to other centres and practitioners. The members of the networks were selected by the Member States of the Community, and consisted of established rehabilitation centres, training institutions, integrated schools etc. The Commission established a team of experts to monitor the Action Programmes. These experts guided the work of the networks, and played. an important role in selecting key annual themes and distributing information to the members. Under the early Action Programmes the Commission covered some of the running costs of the participating centres, as well as funding exchange wisits and conferences. However, the support given to cover daily

* Communication from the Commission to the Counct, the Europiesn Paintament, the Europeran

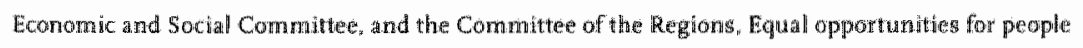
prith disabilitis: A Europen Action Plan, COM (2003) 65o final The three wpertional obfectives" of the Action Rlan are: achieving full application of the Framework Employment Directive; reinforcing mainstreaming of disability issues in relevant Community policies; and improwing acoessiblity for all. See section $3 \mathrm{Ci}$ for further information. 
expenses was absent from later Programmes as it was felt that this encouraged dependence on Community funding which would only be available for a limited period.

It clear that the European Networks benefited hose centres which participated in them, but it is difficult to quantify this benefit, or indeed to assess whether participation resulted in any long-term gains. It is unlikely that the many centres and organisations which were not members, but which nevertheless operated in the fields covered by the networks, profited from the work carried out during this period.

\section{b. Handynet}

In 1983, under the "First Community Action Programme on the Social Integration of Handicapped People (1983-1988)" the Community began work on the "Handynet" project. This was supposed to be a long-term action aimed at establishing a computerized multilingual information system on dis* ability questions throughout the European Community'. Support for Handynet was also provided in the two subsequent Helios Programmes. 9 Progress on Handynet was slow, and the project proved to be both very expensive and relatively unpopular with disabled people. This prompted the European Parliament to frequently criticise the project, and, at the end of Helios II, the project was. quietly dropped. Today, in the age of the Internet, it is difficult to envisage the value of a project such as Handynet.

\section{c. Other Initiatives}

The Helios Action Programmes also provided financiall support for one off conferences and meetings. These meetings were frequently organised by disability Non-Governmental Organisations themselves, and were usually followed by the publication and distribution of reports. In addition, the Helios team of experts also produced a series of multi-lingual newsletters and magazines, which were very widely distributed.

\section{B. Policy Initiatives}

\section{Employment}

The first broad policy instrument specifically addressing disability that was produced by the Community was a Recommendation and

9) In 1994 , shortly before funding for Handynet was withdrawn, the sizth version of the Handwnet CD. ROM was distributed to no information centres. At that time the databage contained rearly 48000 ittems on tefuncal aides and the organis ationg which manufactured and distributed to then. Helios Fhash mentetter, No. 4. April-May 1994.2. 
Guideline on Employment. The Recommendation, adopted in July 1986, was a non-binding document, which only advised Member States on the action they should take to promote the employment of disabled people. The Recommenda. tion itself is a vague document which refers to the need to promote "fair oppor: tunities for disabled people: Annexed to the Recommendation is a "guideline framework for positive action to promote the employment and vocational training of disabled people'. The text of the guideline is relatively precise and does define in clear terms what actions Member States should consider taking in the fields of e.g. job creation, sheltered employment, guidance, assessment and placement, employers and workers" organisations and social security.

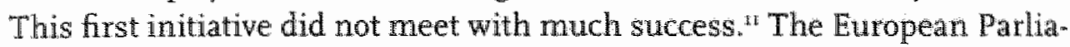
ment criticised the Recommendation for being both 'unambitious and too general ${ }^{3 x}$, and in spite of Commission claims that the Recommendation resulted in progress being made at the national level, ${ }^{3}$ there is little empirical evidence to show that this was so. This fact is confirmed by the Commission functionnatire who was responsible for drafting the text who subsequently wrote: 'In some ways the outcome of [the] employment initiative ... was disappointing.' ${ }^{4}$

\section{ii. Transport}

The relative lack of success of the first, non-binding, policy instrument may have prompted the Commission to propose that its next instrument take the form of a Community directive. In 199 r the Commission proposed a Directive on Minimum Requirements to Improve the Mobility and Safe Transport to Work of Workers with a Reduced Mobility. This proposal was based on Article rr 8 a of the Treaty in force at the time." which allowed for measures to promote the health and safety of workers. The draft Directive

Ho Council Recommendation $6 / 379 / \mathrm{EEC}$ of $24 / \mathrm{July} 1986$ on the Emplovmetht of Disabled Peogle in the

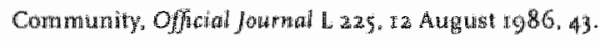

" However, Robert Geyer argueg, in reference to both the action purogrwmen and the recommendatom

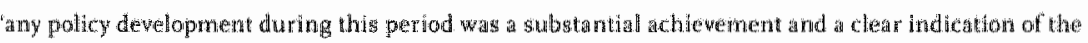

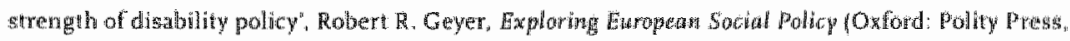
$2000) 189$

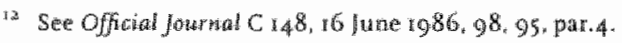

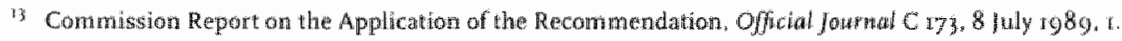

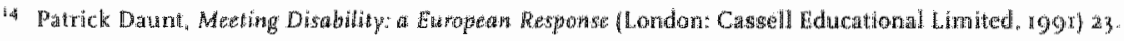

is COMloois8.8 fral.

16 The relevant provisions of the Article read:

t. Member States shall pay particular attention to encowaging mprovenents, especially in the workint

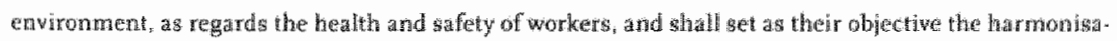
hor of conditions in this area, while maintaining the improventents made.

2. In order to help achieve the objectire laid down in the frest paragraph the Cound I. I shall adont by

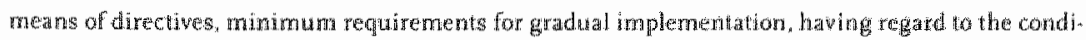
bons and technical rutes obtaning in each of the Member states." 
covered three forms of transport to work: public transport, transport provided by the employer and special transport services for disabled people. The aim was to ensure that whatever form of transport was provided was safe, and a short annew to the proposal gave some vague guidelines on how this was to be achieved.

Although three forms of transport are referred to in the draft directive, the Commission's preference was clearly for public transport. If public transport was accessible to disabled workers travelling to and from work, it would obviously also be accessible to disabled people who made non-work related journeys. The Commission felt it could not propose a directive to directly achieve this more general objective, as the Treaty, at that time, did not provide a suitable legal basis. It therefore felt forced to use this indirect route, relying on health and safety for workers, rather than clearly legislating for accessible public transport. The reaction of Member States, through their representatives in the Council, was poor. On the whole this proposal was perceived as going beyond health and safety for workers, and. Article n8a was seen as an inappropriate legal basis. The proposal was therefore not adopted and died as a result of neglect.

\section{Other Funding Programmes}

In addition to policy instruments, funding was directed towards disability related projects. Some of the projects that participated in the early Action Programmes were funded by the European Social Fund. This Fund, which is one of the Structural Funds," is used to support employment and training initiatives. It is targeted at the most disadvantaged regions in the EU, although all areas receive some degree of funding. Most of the European Social Fund is directed towards exclusively national projects. Money is not usually reserved specifically for projects supporting disabled people, although such projects can apply, and do receive support. However, in the early rggos about ro per cent of the Fund was invested in transnational projects, ${ }^{8}$ involving at least three Member States. One of these transnational projects, HORIZON, 20 was targeted exclusively at disabled people, and it proved to be a popular funding programme.

\footnotetext{
1) The four stuctural funds ane the Europea Social Fund (to promote integration in the labour market).

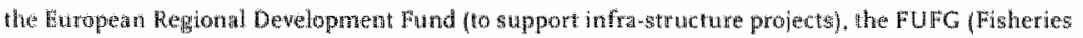
Fund) and the BACP Agriculture Fund).

14 The Community Initiathes.

19. The aim of the HOR $20 \mathrm{~N}$ project was improwing "the labour market extry opportuntites for margin" alised sections of society such as the disabled [sic] and certain onher disadvantaged groups". Guide to Community Human Resources Inithatives - EUROFORM - NOW - HORIZON, 8 March Y991, V/80/91.

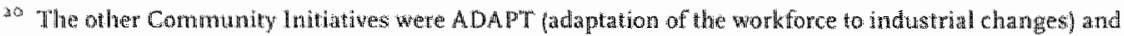
the four Emplowment Initiatiwes: HORLZON, Youthstart, WOW (women), and INTEGRA (other disatvantaged groups
} 
A number of other funding initiatives, such as TIDE (Technology Initiative for Disabled and. Elderly people), ${ }^{21}$ were also targeted at disabled people at this time. However, most funding programmes are not reserved exclusively for this group, and this remains the case today, particularly so since the HORIZON project is no longer operational. This means that projects supporting disabled people must compete with other applicants in order to receive finance. However, a recent change to the Regulations regarding the Structural Funds is important in this respect. As a result of an agreement reached by the Ministers of Economy and Finance in May 2006 accessibility for disabled people should shortly become a requirement before Structural Funds can be awarded. ${ }^{\text {sa }}$

In addition, as of 2000 a new transmational initiative, EQUAL, funds projects aimed at combating all forms of discrimination and inequalities in the labour market, and projects serving this goal with regard to disabled people are funded under this programme. This can be reganded as the (more mainstream) successor to HORIZON.

\section{General Community Policies Overlooking Disability - Some Examples}

The absence of a reference to disability in the Treaty not only limited the Community's ability to introduce measures specifically aimed at disabled people during this period. At a time when the Community had yet to make a commitment to disability mainstreaming, this absence also contributed to the failure to consider the position of disabled people when producing more general legislation and policy. The result was a number of proposals for legislation, and adopted legislation, which indirectly discriminated against certain groups of disabled people.

One area where this occurred was the harmonization of national legislation to achieve the internal market. Under Article 95 EC (prior to 1999 the corresponding Article was rooa EC) the Community is, inter alia empowered to set common design standards for goods and to guarantee free movement throughout the Member States for goods which meet these standards. During the rg9os the needs of disabled consumers were sometimes overlooked when such standards were proposed or set. For example, the 1991 directive on the mutual

24 THDE amed at encouragimg the creation of a single market in rehabilitation techologies and at ensuring coordination and corporation between research centres users organiswtions and compantes operating wh this freth.

3a This requirement is now contained in Article 4 of the General Regulation. Sed European Disability Forum Press reledse, $M$ May 2006.

2\% Communication from the Commission to the Member States establishing the guddelines for he Community Initiatiwe EQUAL of 14 April 2000 concerning tramsmational cooperation to promote new means of combating all forms of discrimination and inequalitues in connection with the labour market. Offucia! Jourmal C 127.5 May 2000, 2. 
recognition of telecommunication terminal equipment set certaim minimum standardg that had to be met by producers of such equipment in order to achieve free circulation within the European Union. ${ }^{24}$ These standards did not include the requirement that the equipment be suitable for use by people with a visual impaiment, and the result was to undermine national legislation, such as that in the United Kingdom, which did include this requirement. Numerous other proposals for (single market harronization) legislation also failed to take the (accessy) needs of disabled people into account; the lifts directive ${ }^{25}$ and the draft of the buses and coaches directive ${ }^{2 \text { tr }}$ did not initially require that new lifts and buses be accessible to people who use a wheelchair, or who have certain other disabilities, wherever possible. It was only comprehensive campaigning by disability Non-Governmental Organisations and members of the European Parlia* ment which rectified this situation. Furthermore, free movement of persons legislation rarely took account of the fact that disability can impose additional barriers on those who wish to take up employment, set up in business, study in or simply move to another Member State. ${ }^{\text {y }}$ The result of this invisibility of disabled EU citizens in the Treaties was a package of Community legislation which, on the whole, ignored disabled people, and in so doing, helped to perpetuate

2.4 Directive $91 / 263 / \mathrm{kEC}$ of 29 April 199 on the approximation of the laws of the rmember states concerning telecommuncations equipment, including the mutual recognition of their conformity, Offical four wal L 128,23 May 1991, A, Article 4 . This Directive was revised in 1999 and now includes non binding reference in the preamble regarding access for dis abled people to radio and telecommunications equipment. See recital $x$ of the Protocol to Directive $1999 / 5 / E C$ which reads: Whereas telecommunications are important to the well-being and employment of people with disabilities who represent a substantial and growing proportion of the population of Europe" whereas radio equipment and telecommunications terminal egupment showld therefore in appropriate cases be designed in such a way that disalbled people may use it without or with only mintmal adaptation'.

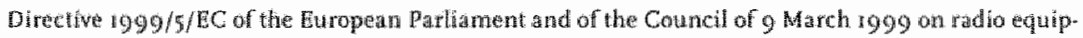

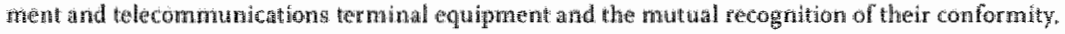

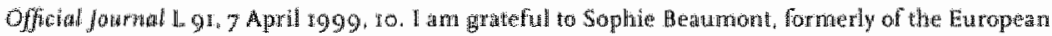
Disatbility Forum for prowiding this information.

25 Directive $99 / 16 / \mathrm{EC}$ of 39 Jube 1995 on the approwimation of the Iaws of the Member Sitates telating to

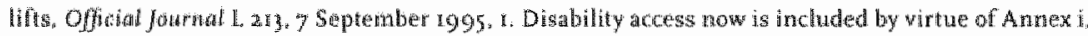
Ar: 1.2.

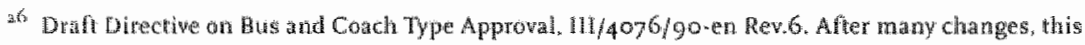
proposal became Directive a00/85/EC of the European Parhament and of the Coumcil of 20 Nowember 2oon relatug to special prowision for vehicles used for the carrage of passengers cornprising more than eight sute in addition to the driver"s seat, offowal Jow information, see section $3 \mathrm{~B}$ ofllihis paper.

s) For an example of a jud grment by the Europen Court of lustice whith argubly discrimates agairst

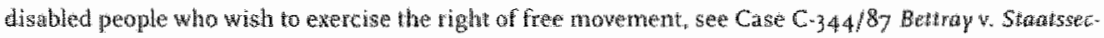

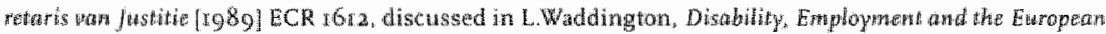
Conmuniny (London: Blackgtona, 1995). 
the disadvantage which they already laboured under. This was challenged in the MGO campaign to secure a reference to disability in the Amsterdam Treaty and, specifically, the inclusion of non-discrimination clause and a reference to disability mainstreaming with regard to the internal market. The campaign's slogan was 'Trvisible Citizens', and it emphasized both the lack of access of disabled people to the benefits of EC policies and the ways in which this problem could be addressed through Treaty amendments. ${ }^{2} \%$

\section{E. Reflection on the State of Play in the mid r9gos}

Whilst many of the disability specific initiatives adopted during this period were important to those organisations that received funding, their overall impact was minimal. This was especially true of the policy initiatives. Member States were reluctant to accept binding obligations at this time, and unwilling to comply with recommendations requiring concrete changes. Today it is difficult to identify improvements, originating in the European Community legal order during this period, which have benefited disabled people.

As a consequence of this lack of influence of EC law, in 1993 our wheelchair traveller may have found a train to take her from Luxembourg to Maastricht where the version of the Treaty that was then in force had been signed, but there was no guarantee that our traveller would have been able to board even the newest of the train carriages on the route - indeed she probably could not have. If she fancied some light reading during the jou mey and picked up the EC Treaty by mistake - before or after the Maastricht Treaty was ratified - she would have looked in vain for a reference to disability or disabled people. And arriving in Maastricht, liking the city, and deciding to apply for a job here, she would have no legal protection from discrimination on the grounds of disability. Of course, if she had nevertheless found a job, she could have had access to the same benefits offered to disabled Dutch workers, by relying on the principle of nom-discrimination on the grounds of EC nationality and the right to free movement. $^{29}$

28. T. Degener et al Europear Day of Disabled Persions, December 7, 1995. Furopean Parliament D/1995/7560/2.

29. Provided for in Arricle 1 EC and a wide range of secondary legislation addresing the right of free

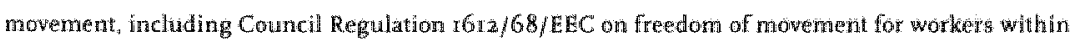
the Community, Official Journal SEd. $1968 \mathrm{~L} 257,2$ amended by Directiwe $2004 / 38 / \mathrm{BC}$ of the European Parliament and the Council of 29 April 200 , on the right of the citzems of the Union and their family

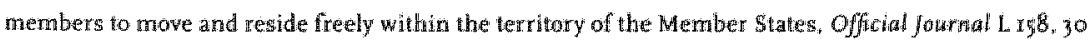
April 2004,77 and Directive $68 / 360 /$ EEC on the abolition of restrictions on movement and residence whithin the Community for workers of Member States and their families, Offolal Journal $8 \mathrm{Ed} .1 \mathrm{~L}$ a 57,13 which has now been repealed by Directime $2004 / 38 / \mathrm{EC}$. 


\section{European Community Disability Policy, 1995-1999}

To return to my own travels. wo years to the day after I defended my Ph.D., on 6 December 2003 in Florence, I was in Italy again - in Rome, speaking at the closing event of the European Year of People with Disabilities. The intervening decade had seen a huge silht in the EC's understanding of disability issues and approach to disability policy. Our wheelchair traveller had come a long way from Maastricht and, I think, was one of the soo people in the audience in Rome. I had also come a long way, and also from Maastricht. When I arrived I had something to say: I told the audience about a European Directive prohibiting disability discrimination; ${ }^{30}$ how in the United Kingdom legislation prohibited disability discrimination in the area of employment, but also access to goods and services; how Belgian federal law prohibited disability discrimination with regard to access to and participation in economic, social, cultural and politicall activity; ${ }^{32}$ how Spanish non-discrimination law required that public places, products and services were accessible for disabled people; 3 how in Sweden the Disability Ombudsman's office included a national Accessibility Centre and how the Ombudsman was the key public institution for the promotion of equal rights. ${ }^{34}$ How here in the Netherlands, the Equal Treatment Commission could hear complaints of disability discrimination for the first time. ${ }^{3}$ How Dutch law provided a clear obligation on employers to adapt the workplace to allow a disabled individual to take up employment, even where this costs the employer money. ${ }^{36}$ How in France ${ }^{37}$ and Belgium ${ }^{38}$ discriminating against some-

10 Council Dirediwe $2000 / 78 / \mathrm{EC}$ of 27 November zooo establishing a general framework for equal treat. ment in employment and occupation, Offichal jouratal \& 303,2 December $2000,16$.

31 Disability Discrimination Act 1995 .

32 Law of Is February 1993 establithing the Centre for Hqual Opportunities and the Fight Aganst Racism.

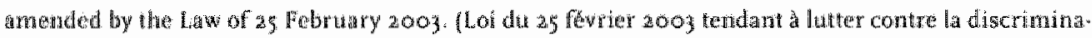

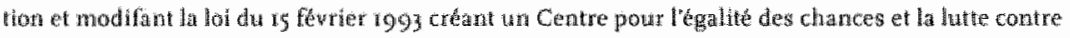

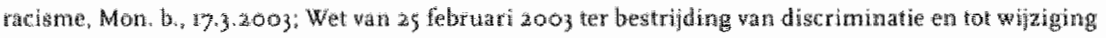

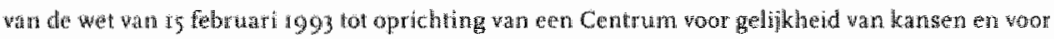
racismelyestrifing

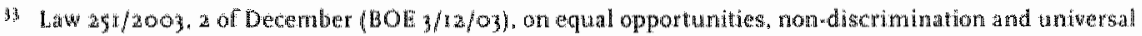
aceessibility for dis abled people.

34 See the homepage of the Swedish Disability Ombudisman:

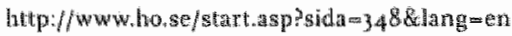

15 Aot of 3 April 200 to establish the Act on the Equal Treatinent on grounds of Disability ar Chronic llluess (Wet ven 3 april 2003 tot waststelling wan de wet gelipke behandeling op grond van havdicap of chronische zidekte).

3. Article 2 of Acr of 3 April 2003 to establish the Act on the Equal Treatment on grounds of Disability or Ghonic Illness.

y) Law No. 90.602 of 1 al Jly rogo concerning the protection of persons against discrimination on

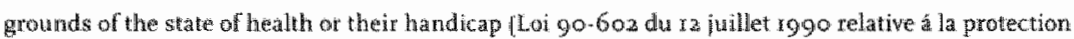
des persomes antre les discritminations en raison die leur e̊́tat de santé ou de leur handicap). 
one on the grounds of disability was a criminal offence; and I told the audience how much influence, direct and indirect, EC law had in this area. 1 could do all this because I had one of the longest speeches in Rome - I had 8 minutes. If the organisers had given me more time. I would have told the audience about how the previous decade had seen the development of a European Community disability policy. I now have more time, and that is what I want to tell you about.

Let me begin by informing you about developments in the second half of the 1990s.

\section{A. A Philosophical Change}

i. From the Medical Model to the Social Model of Disability ${ }^{39}$

Up until 1996 one could argue that the Community's approach to, and understanding of, disability was underpinned by the medical model of disability. ${ }^{4}$ This model holds that the problems related to disability result from the physical or mental impaiment that an individual has, and are largely uncon. nected to the surrounding environment. Disabled individuals are expected to adapt to the prevailing norms and standards in society. Where this is not possible society provides charity for those disabled individuals who are unable to support themselves through employment. This medical model, or charity model as it is sometimes called, dominated the formulation of disability pollicy within European countries for years, if not centuries. It provided a theoretical justification for practices such as the institutionalisation and segregation of disabled people. In the sphere of employment, the model led to an almost exclusive focus on rehabilitation and vocational training, and income maintenance for people who were classified as unable to work.

This model can be contrasted with a social model of disability. The social model is based on a socio-political approach which argues that disability stems primarily from the fallure of the sociall environment to adjust to the needs and aspirations of people with impairments, rather than from the inability of people with impairments to adapt to the environment. The argument here is that it is discrimination, in both the physical and attitudinal environment, prejudice, stigmatisation, segregation and a general history of disadvantage, which we have come to associate with impairment - but which need not be associated with

3: Article 6 of the Law of If February 199 establishing the Centre for Equal Opportunities and the Iight Against Racism, amended by the Law of 25 Fobruary 2003.

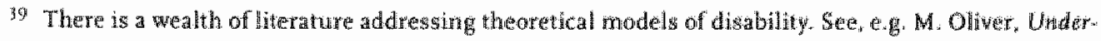

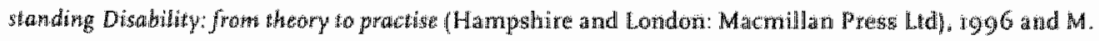

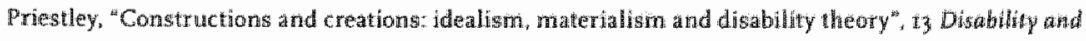
Sority 119981.7594

40 For example, 'distbled people' were defined as All people with aerious disablitueg resulting from phys. cal or mental impairments" under the Helios I programme (A ricile 2 of the promammel. 
impairment -, which is the major problem. According to this perspective, the difficulties confronting disabled people arise from the disabling environment rather than from the individual's impairment. At its most extreme, this model holds that disability is purely a social construction. This model also implies that society has the responsibility to adapt to meet the needs of people with impairments. This last point has been elaborated on in a Commission Communication that has noted the emphasis on identifying and removing the various barriers to equal opportunities and full participation in all aspects of life' and argued "c]hanges in the way we organise our societies can substantially reduce or even overcome obstacles found by people with disability [sic]".4.

\section{ii. The Beginnings of a Global Policy: the Commission Communication and Council Resolution on Equality of Opportunity for People with Disabilities}

In 1996 both the Commission and the Council took the first steps towards developing a global disability policy, and recognised the social model of disability.

In July 1996 the Commission adopted a Communication on Equality of Opportunity for People with Disabilities, the subtitle of which was 'A New European Community Disability Strategy". ${ }^{2}$ This was the first comprehensive European Community strategy produced by the Commission and was inspired by the United Nations Standard Rules on the Equalization of Opportunities for Persons with Disabilities. ${ }^{44}$ "The Commission Conmunication is clearly based on the social model of disability, and as such marked a major step forward in the Commission's thinking. The Communication notes that the way in which society is organised serves to exclude disabled citizens, ${ }^{45}$ and speaks of the evolution towards 'an equal opportunities model in the field of disability policy" within the Member States of the EU. The Communication states:

4i It is interesting to note in this respect hat, according to the current Eu Disability Action Plan (Cqual opporturities for people with disabilities: a thropenn Action Plan, COM (2003) 6ro fral, 4): "The rU atso sees disability as a social construct. The $\mathrm{E} U$ social model of disability stresses the erwionmental barriers in society which prevent the full participation of people with disubilities in soc fety. These barriars must bermowed:

is Communication of the Commission on Equality of Opportumity for People with Disabiliter of 30 fuly 1996$, COM 196$) 406$ final. paris.

43 Communication of the Commision on $\mathrm{B}$ quality of Opporturity for People with Disabilities of 30 fuly 1996. COM (96) 406 find.

44 United Nations General Assembly Resolution $48 / 46$ of 20 December 1993.

4) Communication of the Commission on Equality of Opportinity for People with Disabilitiex of 30 July 1996. COM 196$) 406$ final, par.

${ }^{46}$ Conmunication of the Commission on Equality of Opportwnity for People with Disabilities of 30 July 1996, COM $(96) 406$ hinal par.20. 
'The core value of equality - rendered here as equal opportunities - is now seen as the central benchmark against which economic and social structures must be assessed. It forms the essence of the rights-based approach to disability. The equal opportunities ideal is of course broader than that, but nevertheless subsumes the principle of non-discrimination. ${ }^{4}$

The aim of the Communication was to give a renewed impetus towards the right-based equal opportunities approach to disability' "The Communication prowides for civic dialogue with Non-Governmental Organisations and is based on what the Commission referred to as 'mainstreaming". This is described as entailing:

"the formulation of policy to facilitate the full participation and inwolvement of people with disabilities in economic, social and other processes, while respect. ing personal choice. It allso means that the relevant issues should no longer be considered separately from the mainstream policy-making apparatus, but should be clearly seen as an integral ellement. ${ }^{49}$

In addition to mainstreaming and dialogue with NGOs, the Communication envisaged a strategy consisting of a number of other strands, including political. dialogue with the Member States, so social dialogue between employers and trade unions, strengthening policies to promote the employment of disabled people, harnessing the potential of the Information Society, and using the structural funds to support initiatives in favour of disabled people.5" The Communication was widely praised by disabled people at the time of its adoption.

In December of the same year, the Councillalso approved a Resolution on Equality of Opportunity for People with Disabilities..$^{22}$ In this document, the Council too reaffirmed its commitment to the principles and values of the United Nations Standard Rules and the principles of equality of opportunity and eliminating negative discrimination on the sole grounds of disability. The Resolution called on the Member States, the Commission ${ }^{54}$ and the other

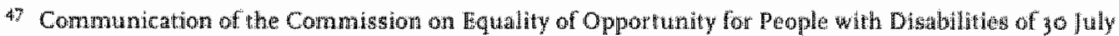
1996. COM (06) 496 tinal, paris.

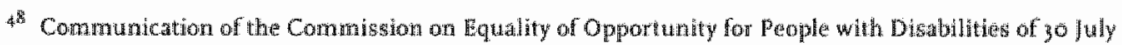
1996. COM (96) 406 final, par.

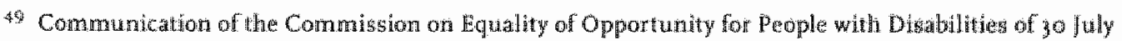
1996, COM (96) 406 firmal, par. 9.

so This was done by establishing a High Level Group of Member States' Representativer or Disability.

si The last whee areas were all examples where anainstreaming approach was to be applined.

52 Resolurion of the Council and of the Representatives of the Covernmernts of the Mcruber States medting within the Council of zo December 996 on equality of opportunity for people whith disabilites, official Jourinal C 12,13 January $199 \%$, 1 .

5s Specifically, the Resolution called on the Member States: 'to congader if retewant mational policieg take into account, in particular, the following orientations: 
Community institutions to take action to achieve the set goals and to promote the involvement of representatives of disabled people in the implementation and follow-up of relevant policies and actions. As ith the Commission Communication, this was a non-birding document.

The Community institutions continue to regularly refer to the philosophical underpinning of disability policy and stress the commitment to the social model of disability. In 2003 , for example, the European Commission reiterated its commitment to the model by stating:

"The EU's long-standing commitment towards its disabled citizens goes hand in hand with a new approach to disability: from seeing people with disabilities as the passive recipients of compensation, society has come to recognise their legitimate demands for equall rights and to realise that participation relates directly to insertion.

In spite of their restricted legal status, the Commission Communication and Council Resolution were highly important. They paved the way for subsequent policy developments, and created the framework within which the Community institutions could respond to the new possibilities opened up by the Amsterdam Treaty in 1999. As a result, the focus of EU disability policy is now far more on conferring rights on disabled people, and particularly the right to equality, interpreted in a broad senge..$^{56}$

- eripowering people with disabilities for participation in socky, incluoing the sewerely disabled. while paying due attention to the needs and interes of their famultes and carers;

- mainstreaming the disubility perspective into all relevant sectors of policy formulation;

- enabling people with disabillties to participate fully in sociaty by removing barters:

- nurturing public opinion to be receptive ta the abilitics of people with disabilinies and toward sitate

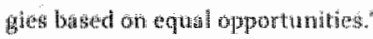

34 The two kney "invitatons' to the Commission ware:

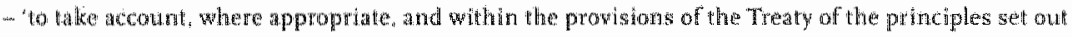
in this Resolution in any refewnt proposal in submits on Community legislation, programmes or initiathiveg:

- to promote - in collaboration with the Membar States and wyth non gover nmentall organizations of

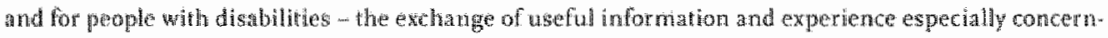
ing innowatipe pollcies and good practice:

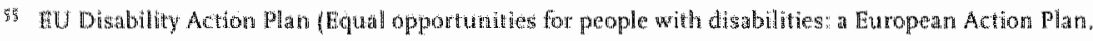
COM (2009) 65omaly, 4 .

s6 For an interesting discussion on the social rnod of disability and the development of a rights based approach do disability within the EU see M. Priestley. "We're an Europeans now" The social model of disability and Europen sacial policy in C. Barnes and G. Mercer (eds.). The Social Model of Disability:

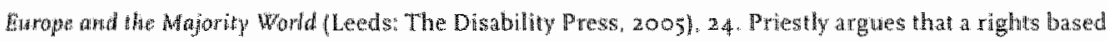
approach is a limited response to the social rooc of disability, and does not challenge "whe social re liavons of production and exchange, and the ways in which these create or sustain disability". 
Howewer, whilst this recognition of the need to use the law to dismantle barriers and combat the discrimination confronting disabled people is highly important, and a prominent theme in today's EU disability policy, it should not be taken to mean that social welfare measures in favour of disabled people are irrelevant or even incompatible with the social model. ${ }^{57}$ On the contrary, EU and national disability policy within Europe, whilst legislating to combat discrimination must also contimue to recognise the value of social welfare measures that do not fit within a non-discriminatory framework. Indeed, it is perhaps the recognition of the need for social welfare measures which serves to distinguish the European approach from its American counterpart, where the emphasis is far more on addressing discrimination, with the goal of allowing disabled individuals to compete (not always with success) in the market. However, European social welfare measures should not undermine the status of disabled people by being based on an outdated and paternalistic medical model, or by restricting the opportunities available to disabled people.$^{58}$ At times, it is a narrow line that policy makers must wallk.

\section{B. The Involvement of Disabled People in Community Decision Making}

A second significant, but related, development also occurred in the r990s. The early Commission disability action programmes were rightly criticised for failing to inwolve disabled people. ${ }^{99}$ In fact network members were

57 Sociall welfre measures are incompatible with the social model of disability where they are based on a medical approach, and serwe to exclude disabled people and deny them a say in decisions affecting their own liwes. Howewer, social welfare pollicies can also be framed within the social model of disability, and serwe as tools to promote equality. In this situation, such neasures are compatible with other policy iools such as nondiscrimination legistation. In fact this topic merits far more attention than I can give

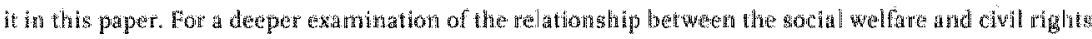

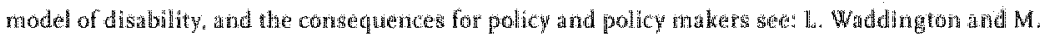

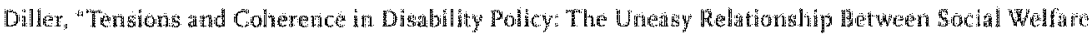

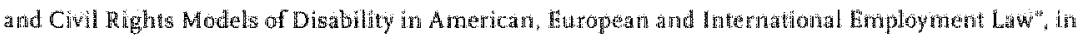

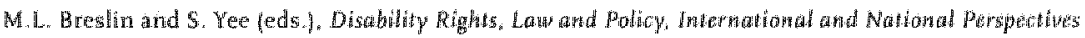
(New York Transnational Publishers, 2002), 241-280. See also A. Hendriks, "Combating Disability

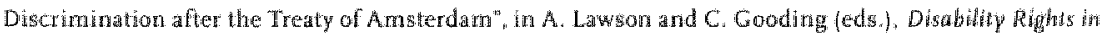

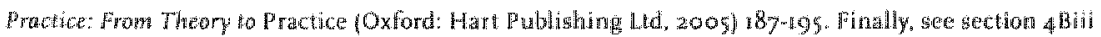
of this paper for a discussion of fourth gemerat ion' equality rights, which allow for the use of son welfure measures.

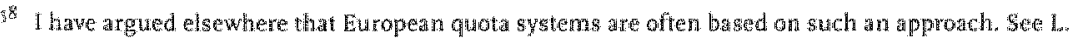
Waddington, "Reassessmg the Employment of People with Disabilities in Europe: From Qubtas to Anti-

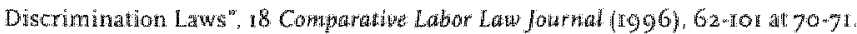

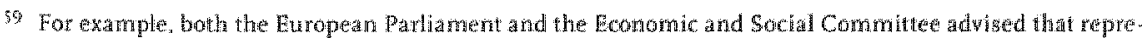
sentatives of disabled peoples should be given a greater consultarive role under the Helios programmes. 
sometimes discouraged from sending disabled delegates on study visits and to meetings, which were targeted at professionals, and some events were organised in buildings which were inaccessible to many disabled people ${ }^{60}$ By the early r990s the approach had changed, and Helios $\mathbb{L}_{*}^{\text {G }}$ and the post-Helios initiatives placed a great deal of emphasis on involving disabled people in all activities. The Helios I programme provided for some limited consultation with representatives of disabled people through a Liaison Group consisting of two representatives from each Member State, nine representatives of disabled people, and one representative each of employers and employees. However, the main consultation group wat the Advisory Committee, which only consisted of the Member State representatives. This system was criticised by the European Parliament and other European institutions: ${ }^{62}$

Helios If had a more intricate consultation system. It established three bodies made up of representatives of Non-Governmental Organisations, Member States, and both groups respectively. The first body was the original European Disability Forum. This consisted of 24 representatives of Non-Governmental Organisations selected by the Commission according to certain criteria related to representativeness and following consultation with the Member States. The European Disability Forum developed a high profile during the four years of the Halios II programme.

\section{i. The Independent European Disability Forum}

Following the demise of the Helios II programme the Forum continued to receive European Funding and became an independent body, electing its own Board and establishing its own constitution. Its membership, which has expanded significantly since 996 , includes the national councils of disabled people from all EU and EEA Member States as well as European level disability NGOs. The national councils are made up of representative national disability NGOs, whilst the broad range of European level organisations represent different disability groups and interests across the Member States.

In its 1996 Communication the Commission welcomed the then recent establishment of the European Disability Forum and committed itself to active cooperation and regular meetings with the For um. ${ }^{63}$ It also stated that it

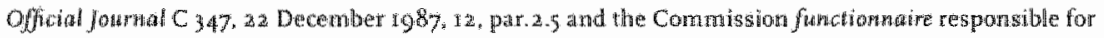
the Disatbility Bureat at the tirne stated that the organisation of the prosramme fell [m... short of what

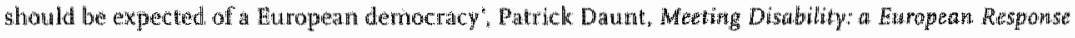
[London: Cassell Educational Limited. 1991 ) 48.

60 House of Londs Select Committee on the Furopean Communities, Session $1987-88$, 13th Repoit, Integration of $\mathrm{Disabled}$ people, Views of Witnesses, page 9 , par.an.

bi One of the four aims of the Helios II action programme was to promote comporation with non-goverinmental organisations representing disabled people.

62 In particular the Bconomic and Social Commoted See foomote 59

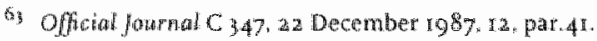


intended to continue to provide financial support to disability $\mathrm{NGOS}$ in order to encourage European co-operation, ${ }^{64}$ and the European Disability Forum, as well as a number of disability specific European NGOs, have continued to benefit from European funding, although this has not always been secure.

Today the independent European Disability Forum has a mandate to campaign at the European level and seeks to represent the interests of the more than 50 million disabled people in the European Union. According to its website '[i]ts mission is to promote equal opportunities for disabled people and to ensure disabled citizens full access to fundamental and human rights through their active involvement in policy development and implementation in the European Union" and its goal is "to defend issues of common concern to all disability groups and be the independent and strong voice of disabled citizens in dialogue with the EU' One of its first major (and successful) campaigns concerned the call for the inclusion of a general non-discrimination Article, which made specific reference to disability, in the run up to the Amsterdam Inter Governmental Conference, and the Forum has campaigned wigorously at all subsequent IGCs.

The Forum liases with the Commission, European Parliament, other Community institutions and the Council of Europe. It also represents European NGOs at the negotiations at the United Nations on the proposed UN Convention on the Human Rights of Persons with Disabilities. The European Disability Forum has regular and structured dialogue with many EU institutions, and is supported in the Parliament by a cross-party Disability Intergroup. ${ }^{66}$ The democratic and representative European Disability Forum, and the strengthened European disiability Non-Governmental Organisations are perhaps the most significant long-term changes that can be associated with the Community action programmes. The Forum itself acknowledges that the Helios II structures "provided an opportunity for disability organisations across the European Union to work closely together across national borders and between different groups in the disability movement', whilst the Commission wrote that the Helios programmes had equipped NGOs [...] to participate more effectively in the democratic process and [...] enhance their self-confidence and awareness of European + wide developments. .6?

\footnotetext{
5.4 Offial journal $\mathrm{C} 347,22$ December 1987,12 par. 40.

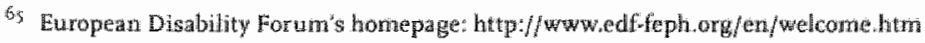

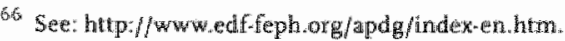

67 Communication of the Commission on Equality of Opportunity for People with Disalbitites of 3 of fuly 1996. COM (96) 406 final, par.39.
} 


\section{European Disability Policy 1999 - Present Day}

\section{A. Changes introduced by the Amsterdam Treaty and the Adoption of the Framework Employment Directive}

From a legal perspective, the major breakthrough with regard to disability policy came with the Amsterdam. Treaty. That Treaty, for the first time, included a reference to disability. The most significant reference occurred in the context of general non-discrimination Article that is still found in Article 13 EC Treaty. 68 "Tis Article provides the Community with the competence to take action to combat discrimination based on sex, racial and ethnic origin, religion or belief, disability, age and sexual orientation. Such action, which can include the adoption of binding legislation, can be taken in all fields where the Community thas competence. 69

Initial doubts as to the impact of the Article, based on its lack of direct effect and the requirement for unanimity within the Council, were soon swept, away with the proposal and rapid adoption of a non-discrimination package. By the end of 2000 two non-discrimination directives, and a non-discrimination action

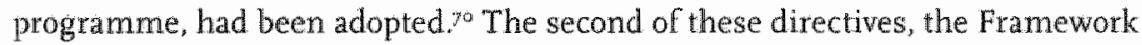
Employment Directive. ${ }^{71}$ prohibits employment-related discrimination on a vari-

68 The first paragriph of the Article provides: without prejudice to the other prowision of this Treaty and with in the limits of the powers conferred upon by the Community, the Council, acting unanimausly on a proposall from the Commission and after consulting the European Parliament, may take appropriate action to combal discrimination based on sex, rach or etheric origin, religion or belief, disability. age ot sexual orientation'.

Gy Fon a discussion of the exact compretences provided by Article 13 EC. see $L$. Flynn. "The Implications of Article 3 EC-After Amsterdarn, Will Some forms Of Discrimination Be More Equal Than Others?"

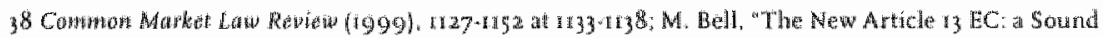

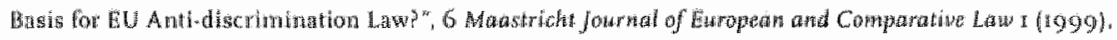

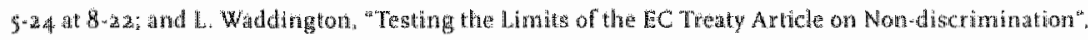

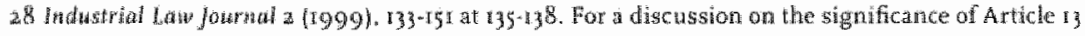

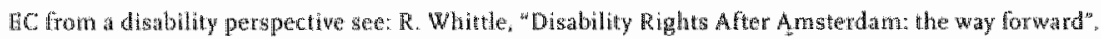

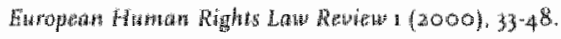

"Directive $2000 / 43 / 6 C$ of 29 lune 2000 implementing the principle of endal treatment between persons

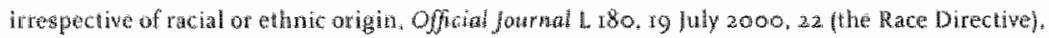
Drective $2000 / 78 / 8 C$ of 37 Nowenber 2000 establishing a genewal framework for equal treatment in

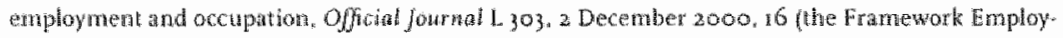
ment Divective and Connd Decision $3000 / 750 / 6 C$ of 27 Nowember establishing a Community action

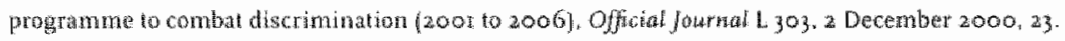

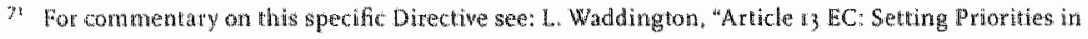

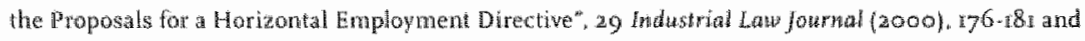
P. Skidnore: "EC Framework Employment Directive on Equal Treatment in Employment: Towards a

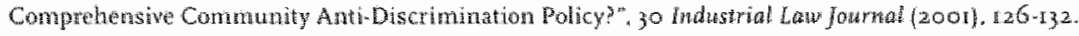


ety of grounds, including disablity. The Directive defines (disability) discrimination as including direct and indirect discrimination, as well as harassment and an instruction to discriminate, ${ }^{92}$ and such discrimination is prohibited in a broad sway of employment and training related areas $;^{73}$ including university education ${ }^{34}$ The definitions of discrimination, and the material scope of the non-discrimination requirement, are identical or similar for all grounds covered by the Framework Employment Directive, and have been amply examined elsewhere.75 From a disability perspective, the provision of most interest is arguably Article 5 of the Directive that requires that reasonable accommodations be made for disabled persons. Although an accommodation requirement could potentially be of interest to individuals and groups other than disabled people, and particularly members of religious minorities, such individuals do not benefit from an equivalent level of protection. $7^{6}$ This obligation in the Directive, and the responses of some Member States to the requirement to establish an obligation. to accommodate disabled people, are examined in more detail below.

For a browder commentary, which covers both the Framework Employnent Dinective att the Race Directive see: M. Bell, "Article 13 EC: The European Commission's Antidiscrinimation Proposals", 29 Industrial Law faumal (2000), 79.84, Lord Lester. "New European Equality Measures" (2000) Publia: Law $562-567$; S. Fredman, "Equality: A New Generation?", 30 Industrial Law Jownal (20019, 145 -68:

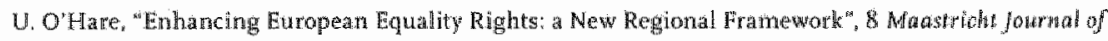

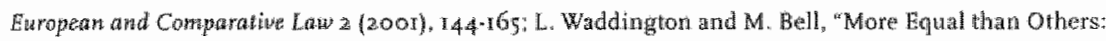

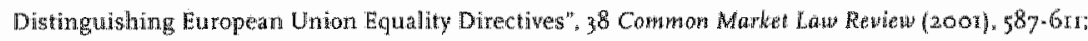
M. Bell and L. Waddington, "Reflecting on Inequalties in European Equality Lawy", 28 Europen Law" Revicw (2003). 3499369 .

72 Article 2 of the Framework Employment Diractive.

7) Article 3 of the Framework Employment Directive.

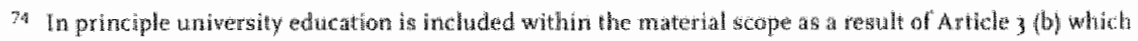
covers access to all types and to all tewels of wocational gudance, wocation

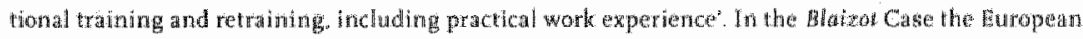
Court of Justice the the the concept of voctional traming could, if certin rather relaxed condilons

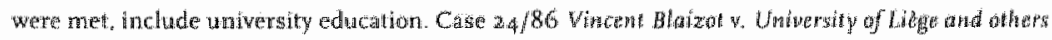
$[19881 \mathrm{ECR} 3 \%$

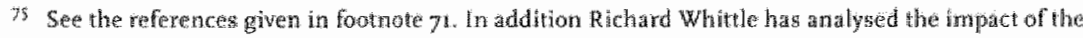

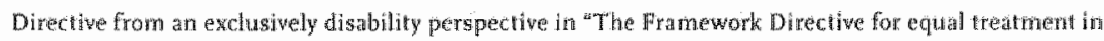

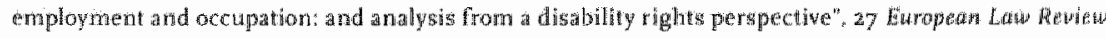

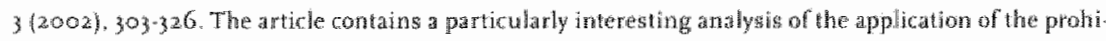
bixion of indirac discrimination wh thega rol to disabled people.

Fe For a discussion on this point, and on the role which the reasonable acconmodition obligation can

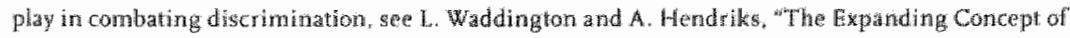
Emplowment Discrimination in Europe: From Dired and Indirect Discrimination fo Reasonable Acom.

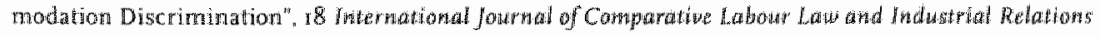
$(2002) \cdot 403-427$ 


\section{i. The Concept of Reasonable Accommodation}

The concept of reasonable accommodation is grounded in the social model of disability, and is worthy of further investigation. The social model of disability recognises that the interaction between an impairment and society can result in disabled individuals being exposed to disadvantage, and the goal of any reasonable accommodation is to eliminate or reduce the disadvantages resulting from such interaction.

With regard to employment, the interaction between an individual's impair ment and the physical or social environment can sometimes result in the inability to perform a particular function or job in the conventional manner. The impairment is therefore relevant in that it can lead to an individual being faced with a barrier that prevents him or her from benefiting from an employment opportunity that is open to others who do not share that impairment. The resulting disadvantage is exclusion from the job market, or a restricted set of employment opportunities. Non-discrimination law is traditionally underpinned by the idea that the protected characteristic, such as race or gender, is rarely relevant to the employment decision and only in exceptional circumstances, such as the bona fide occupational qualification situation, allows for unequal treatment. The protected characteristic should therefore be ignored - the race or gender of a job applicant should play no part, positive or negative, in the decision whether to award the individual the job or not. This is in fact the general position of the Framework Employment Directive. However, as noted above, ignoring, by failing to accommodate, the characteristic of impairment can result in denying a disabled person equal employment opportunities. As Fredman argues:

'Characterising disability as an irrelevant characteristic removes the underlying justification for detrimental treatment, but insisting on similar treatment simply reinforces a particular nom and perpetuates disadvantage."

A reasonable accommodation requirement therefore prohibits an employer from denying an individual with a disability an employment opportunity by failing to take account of the impairment, when taking account of it - in terms of changing tasks or the physical environment of the workplace - would enable the individual to do the work ${ }^{78}$ Employers are required to recognise the impairment and to consider what changes they could make to the work environment to allow a disabled individual to carry out the work to the required standard. 'Instead of

\%) S. Predman, "Digability Equality. A Challenge to the Existing Anti-Discrimimation Paradigm?" in A. Lawson and C. Gooding (eds, Disability Rights in Practer From Thary to Practice (Oxford: Hart Publishing Ltod, 2009199 at a03.

78. Katland and Rutherglen, "Disabilities, Discrimination, and Reasonable Accommodation", 46 Duke Low Journal (1996), I-4r at 9 . 
requiring disabled people to conform to existing norms, the aim is to develop a concept of equality which requires adaptation and change."

Such considerations often arise at the recruitment stage. The reasonable accommodation requirement implies that when comparing a job candidate with an impairment with a candidate without an impairment, the employer must compare the predicted ability of the two candidates after the accommodation has been made. In principle, when making this comparison, the employer is not allowed to take into account that it may cost more to employ the disabled individual, because of the need for an accornmodation. It is only when making the accommodation would amount to what the Directive describes as a disproportionate burden', that an employer can refuse to make the necessary modifications. This is the only acceptable defence to a failure to make an accommodation, and a 'disproportionate burden' is generally assessed in terms of the financial consequences to the undertaking of making the accommodation.

\section{ii. An Examination of the Reasonable Accommodation Provision of the Directive}

Article 5 of the Directive creates the obligation for employers to make a reasonable accommodation for disabled people:

'In order to guarantee compliance with the principle of equal treatment in relation to persons with disabillities, reasonable accommodation shall be prowided. This means that employers shall take appropriate measures, where needed in a particular case to enable a person with a disability to have access to, participate in, or advance in employment, or to provide training for such a person, unless such measures would impose a disproportionate burden on the employer. When this burden is, to a sufficient extent, remedied by existing measures as an element of disablity policy in the Member State, it should not be considered dispropor. tionate.

Given the many intricacies involved in establishing and assessing reasonable accommodation requirements, this provision is perhaps relatively brief. By contrast, the Americans with Disabilities Act 990 (ADA) contains a far more detailed set of provisions on reasonable accommodation, and is accompanied by lengthy explanatory guidance. ${ }^{11}$ However, EC law does provide a limited amount of further information in the non-binding, but infuential preamble to the

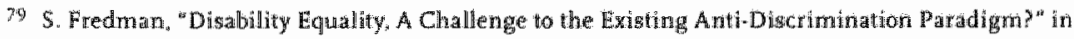
A. Lawson and C. Gooding fedw. Disabilith Rights in Prabtice: Rrom Theory to Practice foxford: Hart Publishing Ldd, 2005 ) 49 at 203 .

\$o Other factors, such as health and safecy risho, can also be relevant.

8. Equal Employment Opportunities Commission (EEOC) regulations the Act. $29 \mathrm{CF}$ ( $1690.2(0)$ ).
} 
Framework Enployment Directive. Recital 20 expands on the kinds of measure that could amount to a reasonable accommodation:

Appropriate measures should be provided, i.e. effective and practical measures to adapt the workplace to the disability, for example adapting premises and equipment, patterns of working time, the distribution of tasks or the provision of training or integration resources."

Some guidance is also given with regard to assessing whether any particular accommodation amounts to a disproportionate burden in recital $2 \pi$ :

"To determine whether the measures in question give rise to disproportionate burden, account should be taken in particular of the financial and other costs entailed, the scalle and financial resources of the orgamisation or undertaking and the possibility of obtaining public funding or any other assistance."

As noted above, the ADA also imposes an obligation on employers ${ }^{82}$ (and others) to make reasonable accommodations for disabled people. It is submitted that this US statute directly influenced the drafting of Article 5 of the Framework Employment Directive. In particular, it is submitted that the term 'reasonable accommodation:" first used in the US Rehabilitation Act of r973 and later incorporated in the ADA, was determinant of the terminology used in Article 5. A conscious choice was made to use the term 'reasonable accommodation' in the Directive because of the level of familiarity with this particular element of the ADA amongst relevant Commission staff, some Member States, and disability NGOs. Furthermore, the term "reasonable accommodation" in the Directiwe was, arguably, intended to convey the same meaning as it has in the ADA, or at least the meaning the term had when the Act was originally adopted. ${ }^{8_{3}}$ In this context, a 'reasonable accommodation' with regard to the Directive should be seen as a modification or adjustment that is effective in enabling an individual with a disability to perform the essential functions' of a particular job. The question of reasonableness, as understood in this way, is therefore quite separate from the analysis telating to existence of an undue hardship or disproportionate

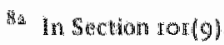

8. The meaning of the term "reasonable w nder the ADA must wow be understond in light of the 2002

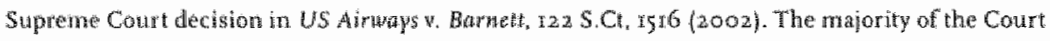
gave independent significance to the term 'reasonable' reganding it as a modifier to the duty to make an acommodation. The majcrity opinion of hustice Breyer stated in ordmary tenglish the word "reasionable" does not mean "eftective". It is the word 'accommodation', not the word "reasonable", that conveys the need for effectiveness:. See also A. Meyersora and S.Yee, "Reasonable Accommodation after Harnett", Paper for the National Council on Disability, wwwnd.gov. 
burden for the employer. ${ }^{8}$ However this interpretation does not seen to have been made explicit in the Directive or its Preamble, and this may create confusion at the implementation phase.

\section{iii. The National Impact of the Requirement to Establish a Duty to Accommodate}

At the time of the adoption of the Directive the concept of reasonable accommodation was foreign to most Member States and accession States. Only the United Kingdom, ${ }^{35}$ Ireland ${ }^{86}$ and Sweden ${ }^{87}$ had recognised such an obligation within their national laws, and indeed only these three Member States had disability non-discrimination legislation ${ }^{88}$ on their statute books at all. The brevity of the Directive in establishing the reasonable accommodation requirement provided relatively little guidance to the Member States on how they were to transpose this obligation into national law. Questions that may still arise concern the entitlement to claim a reasonable accommodation, ${ }^{3}$ the extent of the obligation on employers to make an accommodation, the means by which an appropriate accommodation should be identified and the point at which employers can argue that a disproportionate burden exists, amongst others. 90

4. For further commentary or the orighal interpretation of the reasonable accommodation provision

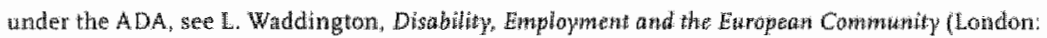
Blackstone, ng9g/ pr64.16\%.

8. S. 3 A (2), Disability Discrimination Act 1995 .

86 Section 16 . Employment Equality Act 1998 and section 4, Equal Stat us Act 2000

87 Section 6, Disability Discrimination Act 1999

sat The refence here is to non-discrimination legislation within the civil law. Other Member States, and in particular France, had disibility non-discrimination measures within the criminall law prior to the adtoption of the Fumetwork Employment Directwe sed footnote $3 \%$.

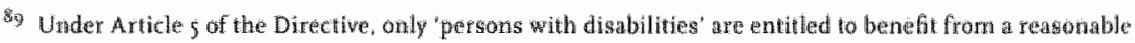

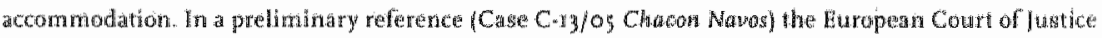

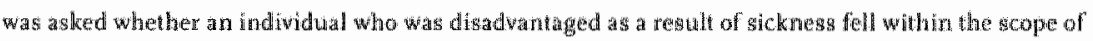

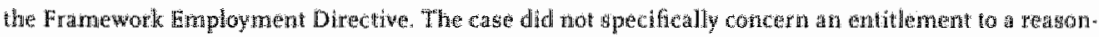
able accommodation, whough the gituestion could also be relevant in this context. Advacute General Geethoed adwiged the Court in his opinion of 16 . Warch 2006 that a sickness that could leat to a luture disability should not be regarded as aquivalent to a disability within the meaning of the framework Employment Directive, and that such an individual did not fall within the scope of the butective The Court has yet to decide on the matter.

sa A paper produced for the European Commisgion Expert Group on Disability Discrimination ident fied eight issues which required further reflection. These were:

Issue wh: What is a 'Reasonable Accommodation'? Issue 2: Is 'Reasonable Accomarnod witon' a Form of Positive Action? Issue 3 : Is it sufficient to establish a negative duty tho accomimodate 1.e. a fallure to accommodate amounts to discrimination, or must a positive duty to accominodate be establisined? 
Ag a consequence Article 5 has been one of the more difficult prowisions of the Directive to transpose.

In response, in some cases, Member States have simply copied the wording of Article 5 into their nationall legislation. This has, for example, occurred in Greece. However, this approach seems to be compounding problems. The text of the Framework Directive is brief and unelaborated. Employers and disabled people will be uncertain as to the extent of the obligation, and courts will be left to interpret the provisions with relatively little guidance or appropriate knowledge.

\section{a. The Netherlands}

Some Member States have opted for a more refined approach to transposing Article 5, and have used different terminology from that found in the Directive in their implementation legislation. The Netherlands is a good example in this respect. The reasonable accommodation requirement has been transposed through Article 2 of the Act of 3 April 2003 to establish the Act on the Equal "Treatment on grounds of Disability or Chronic Illness. ${ }^{93}$ The legislation defines a failure to make an accommodation as a form of differentiation: 9

'The prohibition on differentiation also means that the person on whom this prohibition is imposed is obliged to make effective accommodations where

Issue 4ho Should be that wed to a "Reasonable Accommodation"?

Issue 5: What is the Best Process by Which Indiwatualised 'Reasonable Accommodations' can be Identifred?

Issue 6. What Limits Exist to the Making a 'Rewsonable Accommodation'? When will making a "Reasonable Accommodiation' atmount to a 'Disproportionate Burden'?

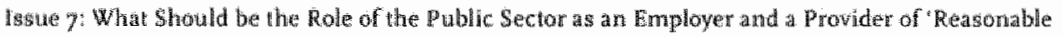
Accomotiodations si what is the revance of the public subsidies?

Issue 8: How does a Duty to Accommodate Githo the Non-Discrimination Fimework?

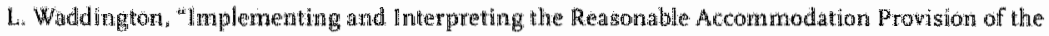

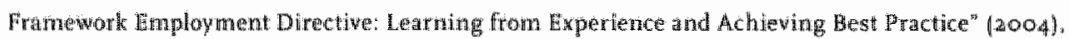
buropan Commission, published at: http//europa eu int/conm/employment_social/fundamental

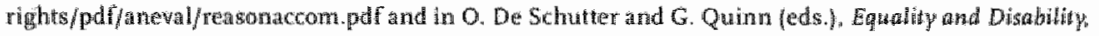
(Bruglant, Fortheoming)

95 Artiche 10 of Antidediscrimitiation Law n. $3304 / 2005$.

git wet wan 3 aprill 200 y tot watstelling wan de Wef gellike behandeling op grond wan handicap of chromische zialkte.

39 Dutch legtshation uses the term "diferentiation. in preference to the term 'discrimination'. See for further taboration Lisa Waddington. in "Implementing the Disability Prowisions of the Iramework Fmployment Directiwe: Rocm for Exercising National Discretion", in A. Lawson and C. Gooding (eds.), Disabulity Rights in Practice: Fromat Thory to Pratetice (Oxford: Hart Publishing Ltd, 2005) ro7. 
meeded in a particular case, unlless this would impose a disproportionate burden on them. ${ }^{.94}$

The first point to note is that the Dutch legislation shies away from the term "reasonable accommodation" ("redelijke aanpassingen") found in the Directive, in favour of the term "effective accommodation' (doeltreffende apassingen'). In doing $\mathrm{so}_{n}$ the Dutch legislature has, arguably, followed the US inspired interpretation of the reasonable accommodation provision in the Directive, and separated the issue of the effectiveness of the accommodation from the question of undue hardship or disproportionate burden. The Dutch Government opted to use the term 'effective accommodation' because this emphasised that the specific accommodation had to achieve the desired effect. ${ }^{25}$ This is judged according to the 'suitability" or "appropriateness' (geschiktheid) and 'necessity" ('noodzakelijkheid") of a specific accommodation.9" In Opinion 2004-140, the Dutch Equal Treatment Commission provided the following clarification of the "effective accommodation" requirement:

"An accommodation must be effective. This means that the accommodation must be appropriate and necessary in order to allow the disabled or chronically ill person to participate in (a certain aspect of) social life just like any other person. An accommodation is appropriate if it removes the restriction, whatever form that may take, and promotes the independence and full participation and integration of the disiabled or chronically ill person.

An accommodation is necessary if there is no other (possibly less costly) provision that can achieve the same goal. ${ }^{9 ?}$

The second, and separate, stage of the assessment involves a consideration of whether the accommodation amounts to a disproportionate burden. This involwes a balancing of the interests of the employer and the disabled person, inter alia, through the application of standard 'open norms' of Dutch civil law (i.e. the duty to act as a good employer and the notion of "reasonableness"). ${ }^{\text {" }}$

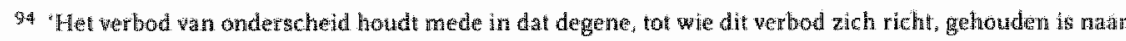

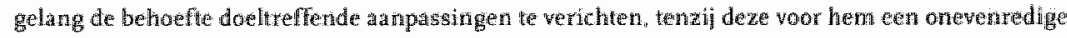
belustig vormen.'

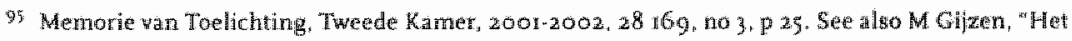

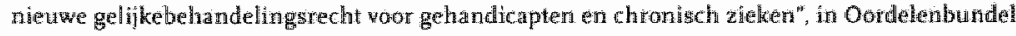
(Utrecht: CGB, 200y), ros at ros:

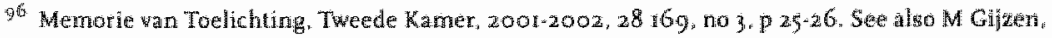
"Fet nieuwe gelikgebehandelingsrecht woor gehandicapten eri chronisch zisken", in Oordelenbundel (Wtrecht: CGB, 2003), rot at ro5.

97 Paragraphs 5.12 and 5.13 . Tranatations are unof ficial and provided by the author.

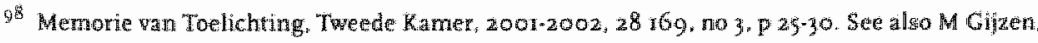
"Het nieuwe gelinkebehandelingsmecht woor gehandicapten en chronisch ziveken", in Oordelenburdel (Utrechit: CGB, 2003), rot at 105 and A. Hendriks, Gelijke Toegang to de Arbeld woor Gehanditaptem (Ph, D Unwersiteit wan Amsterdam, 2000), 18,5187 . 
This clearly defined two stage process will arguably promote clarity and understanding, rather than resulting in a difficult merging of the separate issues of the effectiveness of the accommodation and the extent to which making that accommodation amounts to a disproportionate burden.

\section{b. Belginim}

An alternative approach to the transposition of Article 5 can be found in the Belgian federal legislation which transposed both the Race Directive and the Framework Employment Directive. 99 There was an initial reluctance to include any reasonable accommodation provision in the relevant federal statute A proposal to include such a provision, the wording of which was heavily based on Article 5 of the Directive, was rejected. One of the reasons given for this, by the Minister of Employment, was that the proposal amounted to a form of positive action whilst the national statute in question was only an anti*discrimination measure. ${ }^{100}$ 'The Belgian Federal Government does not have competence to legislate on positive action, and this perception of reasonable accommodation therefore constituted a significant hurdle to legislation at the federal level falthough it would not restrict implementation at other levels of government). ${ }^{\text {ro }}$ Eventually, the inclusion of the following Govermment amendment provided a way round this impasse:

99 Act to Combat Discrimination and to Amend the Act of 15 February 1993 to Establisth a Centre for Equal Opporturyty and to Combat Racism. Some provisions of this law have subsequently been annulled by the Belgian Canstitutional Court (Judgment of the Court of Arbitration of 6 October 2004), and it is likely that the Act will be amended by the end af 2006 in light of this judgment. Howerer. the provi.

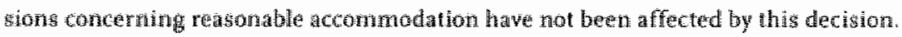

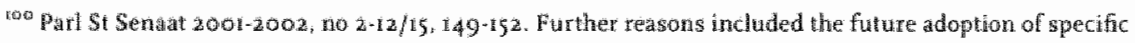
legutation on this topic, and the need to discuts the measure with the social parners. See K. Van den Langenbergh "Discriminate van Gehandicapten bij Aanwerving : Fen Werkernende Analyse" in

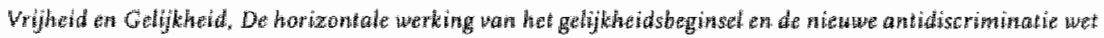

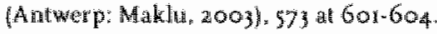

rot The Helugian consitutional structure divides the task of promoting equal opportunitieg for a isabled people between:

- the Federal level, which has the responsibilty for defining non discrimination requirementz in crimi. mal and labour law and by regulating the contract of employment;

- the Regional level, which has the responsibility for promoting the professional integration of disabled people in employment policy:

- and the Communities, which have the responsibility for promoting the rehabilliktion and wocational raning of disabled people.

However. some redent developments have brought about more coherence at the Regional and Community level. 
The denial of a reasonable accommodation for a person with a disability is discrimination in the sense of this statute.

A reasonable accommodation is an accommodation that does not create a disproportionate burden, or where the burden is sufficiently compensated for by existing measures.":

Van den Langenbergh has commented that this provision does not amount to an obligation to make an accommodation, but it does make it clear that a refusal to take account of the situation or a disabled person, by refusing to make an accommodation in their favour, is a form of discrimination. She argues that the provision should not be regarded as a form of positive action and hopes, in this way, to avoid the aforementioned competence problems. ${ }^{\text {ios }}$

One can see from the second part of Article 2(3) of the Belgian statute, that an accommodation is judged to be reasonable if it does not create a disproportionate burden for the employer. This interpretation conflicts with the aforementioned US inspired understanding of the notion of reasonable accommodation, which regards an employment related accommodation as reasonable if it is effective in allowing an individual to carry out a specific job. The preparatory texts relating to the Belgian statute, in fact, make it clear that when determining whether any accommodation amounts to a disproportionate burden (or, in the terminology of the Belgian Act, whether it is reasonable), three criteria have to be considered:

- are any accommodations possible which would allow a specific person with a disability to effectively participate in an equal way in a specific activity?

- do these accommodations amount to a disproportionate burden for the person who must make them?

- do there exist any measures that significantly reduce the burden on the person who is under the duty to accommodation? ${ }^{104}$

Only the last two criteria have been included in the Statute, however, and Belgian law (unlike the Directive and the Dutch implementation proviston) does

\footnotetext{
${ }^{3}$ Article 2 (3): "Het ontbreken van redelinke alanpassingen woon de persoon met een handicap wormt een discriminatie in de zin van deze wet. Als cen redelike anpassing wordt beschouwd de anpassing die geen oneventedige belasting betekent, of wa wan de belasting in woldoende mate gecompenseerd wordt door bestaande matregeller."

10 K. Van den Langenbergh, "Discriminatie wan Gehandicapten bil Aanwerwing: Eev Verkennende

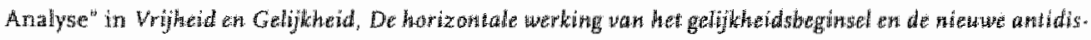
criminathe ontwerp: Maklu, 2003 .

304 Parl 5t 3001-2002, no $578 / 008,30$-31. See K. Wan den Langeribergh. "Discriminatie yan Gehandi.

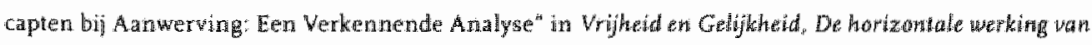

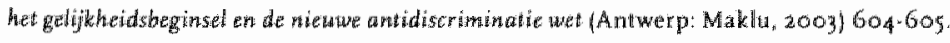


not impose an obligation to make an accommodation to meet the particular needs of an individual.

\section{c. The United Kingdom}

A final interesting example of how national legislation has dealt with the reasonable accommodation requirement can be found in the UK Disability Discrimination Act 1995 (DDA). This statute was adopted prior to the Directive and the UK' experience with reasonable accommodation can have been expected to have fed into discussions on Article 5 of the Framework Employment Directive. The DDA originally prohibited two forms of disability discrimination: disability related discrimination and a failure to make a reasonable adjustment. 'Disability related discrimination' is defined as occurring if a person:

'for a reason which relates to the disabled person's disability, he treats that person less favourably than he would treat others to whom that reason does not, or would not, apply, and he cainnot show that the treatment is justified.":as

Following the adoption of the Directive, the DDA was amended so as to also prohibit direct discrimination as defined by the Directive. ${ }^{106}$ The DDA does not, however, prohibit indirect discrimination, as defined by the Directive. This is because the Directive specifies that action which would otherwise be classified as indirect discrimination shall not be prohibited if:

"as regards persons with a particular disability, the employer or any person or organisation to whom this Directive applies, is obliged, under national legislation, to take appropriate measures in line with the principles contained in Article 5 in order to eliminate disadvantages entalled by such (indirectly discriminatory LW) provision, criterion or practice. ${ }^{\text {not }}$

The inclusion of this provision in the Directive allowed the United Kingdom to continue with its pre-existing approach that did not address indirect discrimina* tion. Instead, under the DDA, in situations that would otherwise amount to indirect discrimination against a disabled person, the employer is obliged to make an individual adaptation to liminate the disadvantage that particular individual experiences. The group-oriented notion of indirect discrimination has therefore been watered down to an individualised approach based on reasonable accommodation.

\footnotetext{
205 S. 3A(I)

106.3 . $3(5)$.

${ }^{10 \%}$ Article $2(2)$ (b) (ii).
} 
The specific "reasonable accommodation" requirement under the DDA provides: '[...] a person [...] discriminates against a disabled person if he fails to comply with a duty to make reasonable adjustments imposed on him in relation to the disabled person. "ros

The term 'reasonable accommodation' is therefore not found in UK legislation. Arguably, it is not clear what the significance is, if any, of using the alternative term "reasonable adjustment" in the DDA. The duty to make such an adjustment arises whenever any physical feature of the workplace or any arrangements made by or on behalf of an employer, place a disabled person at a substantial disadvantage in comparison with a non disabled person or a person who does not have such a disability. ${ }^{109}$ In such a situation the employer is under an obligation to take such steps as may be considered reasonable in order to prevent the disadvantage occurring. The DDA and the accompanying guidelines provide detailed guidance as to what measures amount to an appropriate adjustment and what factors should be taken into account in deciding whether any particular step is reasonable in all the circumstances. ${ }^{1 * 0}$

The extent of the reasonable adjustment requirement can be illustrated by the 2004 decision of the House of Lords in Archibald v. Fife "th The case concerned a road sweeper who, as a result of a disability, was unable to continue in her position. She applied for over a hundred internal wacancies, but was unsuccessful on each occasion as the jobs were awarded to better-qualified candidates. She argued that her employer should have gone further and reassigned her to another position for which she was suitably qualified, without requiring her to compete with other candidates. The House of Lords found in her favour and emphasised the different nature of the DDA when compared to other non-discrimination statutes.

\section{B. Mainstreaming Disability into General EU Policy and Legislation}

Whilst the Framework Employment Directive is probably the most significant legal development in recent years, the Community instutions have also taken other steps to develop a disability policy.

As noted above, the Commission first committed itsel to mainstreaming disability issues into general areas of Community policy in its $1996 \mathrm{Commu}$ nication, and this commitment has subsequently been repeated in a number of other policy documents. The Amsterdam Treaty contained s specific disability mainstreaming provision. According to Declaration 22 to the Treaty the

\footnotetext{
128 DDA, 5.3A(2). Since the coming iryto force of the Disability Discriminution Regulations fn october

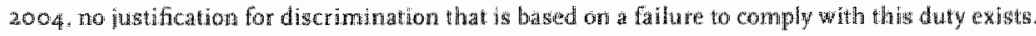


Community institutions must take account of the needs of disabled persons when adopting internal market legislation under Article 95.".: However, such a declaration does not have any legal effect, and it is not possible to bring an action before the Court of Justice if the Commission should overlook this obliga. tion. Perhaps (partly) because of these factors, the internal market has arguably not, thus far been an area where the Commission has pursued a mainstreaming policy with particular vigour. However, the approach has been more fruitful in a number of other areas.

One interesting example of successful mainstreaming concerns transport policy. ${ }^{133}$ As a result of a 200 . Directive ${ }^{14}$ all new buses and coaches in the EU must be designed and built so as to ensure that they are accessible for passengers with reduced mobility. According to the Directive, such passengers not only include certain disabled people, but also people with heavy luggage, elderly people, pregnant women, people with children and even people with shopping trolleys." The accessibility requirements include the mandatory installation of ramps or lifts to all urban buses, priority seating for persons with reduced mobility, a designated area for wheelchairs, space for a guide dog in the vehicle, and colour contrasting to assist visually impaired persons. ${ }^{86}$ In spite of these requirements the primary aim of this Directive was not to ensure the accessibility of urban buses for disabled people, but to guarantee the safety of al] passengers."

"12 The Dectaration veds: "The Conference agres that, in drawing up measing under Article 95, the institutions of the Communty shall bake account of the meeds of persons with a disability. This provision was included in response to concerns woiced by the disability nonement that single market harnonization provisions were resulting in the setting of common standarcs that rendered productsinatecessible to disabied people. For further infomation sec section $x D$ of this paper. For a briefoverview af the arguments used by the disability mowement before the adoption of the Amsterdan Treaty see: "Invisible Citizens. Disabled Persons' Stattus in the European Freaties European Day of Disabled Pergons 1995. Luroperan Parliament D/1995/7560/2 att 16 and 5

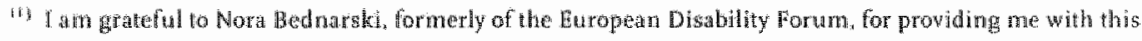
iniformation.

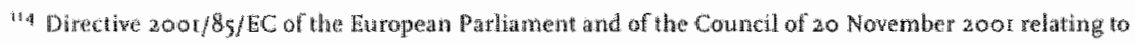
special provinion for wehicles used for the cutrage of passengers comprising more than eight seats in

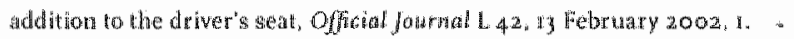

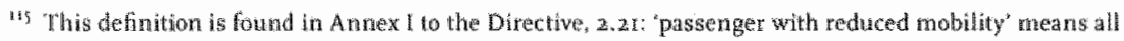
people who have difficulty when wing pubtic transport, such as disabled people finchuding people with

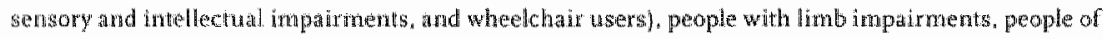
small stature, people with heavy luggage, elderly people, pregnan women people with shopping trol. leys, and people with chaldren (inchding children seated in pushchairs)

"Acossibilly requirements are detaled in Annex Wll to the Diractive.

ai 酸cital if of the preamble to the Directive reads:

"While the principal a im of this Directive is to guaratee the safety of passengers, it us also necessary" to provide technical prescriptions to allow accessibility for persons of reduced mobilaty to the vehicles covered by the Directive, in accordance with the Communty transport and social policies." 
Further examples of disability mainstreaming in transport can be found in the rather uninspiringly named Directive on the interoperability of the transEuropean high-speed rail system ${ }^{\text {rn }}$ and the Directive on the interoperability of the trans-European conventional rail system. "These Directives, and the related technical specifications ${ }^{12 \%}$ require that both the infrastructure of railway stations and train carriages must be accessible for disabled passengers. This implies that disabled people must have easy access to railway stations and all facilities within the stations, ${ }^{\text {":I }}$ and access to trains which should include adapted toilets, space for wheelchairs and sufficiently wide doors. ${ }^{\text {ina }}$ Again, the purpose of these directives was not to ensure accessibility for disabled passengers, but to establish technical specifications for interoperability of trains throughout the EU. As a consequence, these requirements only apply to international trains and the railway stations which they stop at. One can therefore expect a significant impact on the continent of Europe, but the rail network in the United Kingdom and the Republic of Ireland will remain largely outside the scope of this legislation.

Simillar accessibility requirements can be found with regard to passenger ships, ${ }^{13}$ and new legislation is currently being drafted with regard to aeroplane travel. ${ }^{i}{ }^{4}$

In addition to the inclusion of provisions in general directives such as these, the Council of Ministers has adopted a variety of non binding instruments addressing the need to mainstream disability isstues in particular fields. These non-binding instruments, which take the form of Resolutions or Communications, call on the Member States, the Commission and, on occasions, third parties such as the Social Partners, to take action to improve the lives of disabled people in warious ways. Such initiatives thave addressed fields as diverse as

${ }^{38}$ Council Directive $96 / 48 / 6 C$ of 23 July 5996 on the interoperability of the trang- European high-speed

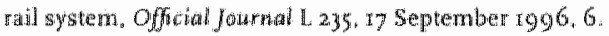

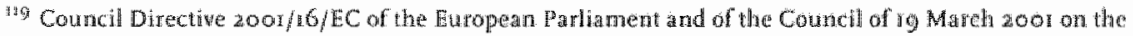
interoperability of the transw Europesn conventional rail system, Offichl fow

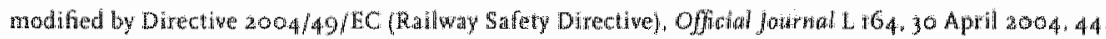

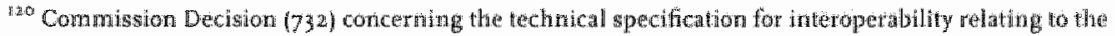

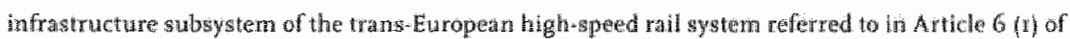

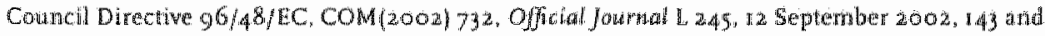
Commission Decision (735) conceming technical specification for inteloperalbility ( $\mathrm{r}$ s 1 s) relating to the rolling stock subsysten of the trans. European high-eped rall system referred to in Directitue $96 / 4.8 / 5 \mathrm{C}$.

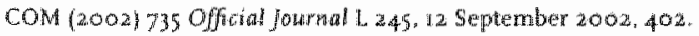

${ }^{12}$ Commission Decision (732), section 4.1 .9 , and Section 4.3 .3 .26 .

$12 \pi$ Commission Decision (735). Section 4 4.12.

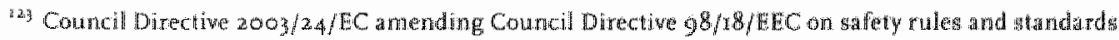
for passenger ships, Offital Journal L 23, noy 2003,18 .

12 GOM $(2005) 47,16$ February 2005 . 
employment and social integration, ${ }^{125}$ culture, ${ }^{126}$ education, ${ }^{327}$ the knowledge based society" and a barrier free society. ${ }^{129}$

It is difficult to assess the impact of such measures. Member States are generally not under an obligation to inform the Commission of the steps they have taken to achieve the set goals, and independent research does not exist. However, one non-binding measure, a 1998 Council Recommendation on the development of a common EC wide parking card for disabled people, ${ }^{30}$ has resulted in changes and benefits across the board. There is now a common $\mathrm{EU}$ format for a disabled parking card, with cards being recognised in all Member States. This success is probably due to the cllear and limited nature of the action required of Member States. Quite appropriately, this was a disability specific instrument and was not part of the wider goal of mainstreaming.

\section{Disability Specific Initiatives}

\section{i. Equal opportunities for people with disabilities: A Euro- pean Action Plan, 2003}

In October 2003 the Commission adopted a new Action Plan designed to 'achieve a sustainable and operational approach to disability." "The Plan was designed to build on the momentum of the 2003 European Year of People with Disabilities and introduced a multi-annual action plan running through to 20ro. "The plan has three central objectives: to implement fully the Framework Employment Directive with regard to disability; to reinforce mainstreaming of disability issues in relewant Community policies (e.g. European strategies for employment and social inclusionj; and to improve accessibility for all. This last goal built on the earlier Commission Communication of May 2000 "Towards a barrier free Europe for people with disabilities", ${ }^{132}$ which stressed

\footnotetext{
13\% Council Resolution of 15 luly 2003 on pronoting the ervploynant and social integration of people with disabilities, Official Joumal 075.27 March 2009.5

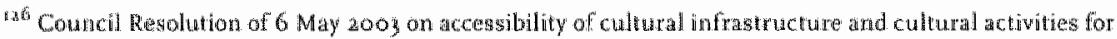

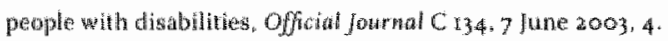

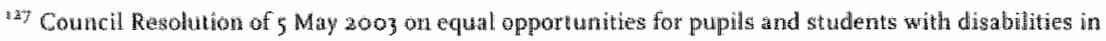

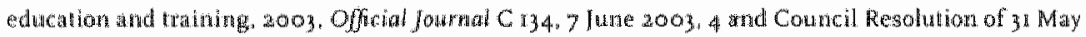
1990 concerning integration of childen and young people with disabilthes into ordinary systems of entucation, Offictal Jomarmal C 162,31 May 1990, 2.

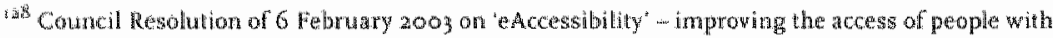

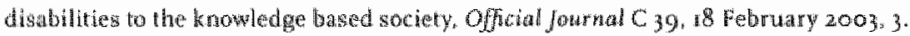

13y Communication from the Commission to the Council the Europern Parliament, the Economic and

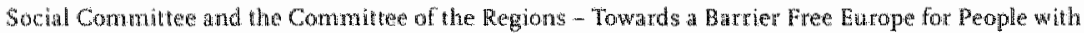
Disabilities, COM (2000) 28 , final. 2 May 2000.

17 Council Recommendation $198 / 376 / 50)$ of 4 llwe r998 an a parking card for people whth Disabilities.

i*1. COM (2003) 6,0 Gmal. 30 October 2003 at 3

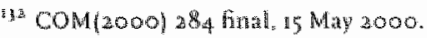


the need to remove the envirommental barriers in society that prevent the full participation of people with disabilities. The first two years of the Action Pan (2004-2005) have seen a focus on creating the conditions necessary to promote the employment of people disabilities. This has involved action regarding access. to, and remaining in, employment: lifelong learning harnessing the potential of new technologies; and accessibility to the public built environment. For the current period (2006-2007), the priority areas are encouraging activity; providing access to quality support and care services for disabled people; fostering accessibility for all; and increasing the Union's information gathering and analytical capacity. ${ }^{13}$

\section{The Nice Treaty and the EU Charter of Fundamental Rights}

To return to our wheelchair traveller. She has now reached Nice where the Treaty that is currently in force was signed. She has enjoyed travelling in an accessible new train carriage, and found her study of the EC Treaty and related legislation to be far more rewarding than it was on her journey to Maastricht. She discovers that no disability significant changes to the Treaty were made in Nice. However, her journey was not in vain, for Nice also saw the adoption of the EU Charter of Fundamental Rights. The Charter is rooted in the right to human dignity and, although it is currently a non-binding document, it should nevertheless be respected by the Member States and the EU institutions. In addition, the new EU Constitution, which has yet to be adopted, incorporates the Charter.

Two explicit references to disability can be found in the Charter. Firstly, Article 2 prohibits any discrimination on any grounds, including disability and genetic features. The scope of this Article extends beyond employment, although its legal impact is significantly different, and significantly less in terms of justiciable rights, than the Framework Employment Directive. This will not change if and when the new Constitution comes into force.

Article 26 of the Charter is explicitly concerned with disabled people. Under this Article the Union should recognise and respect the rights of disabled people to benefit from measures designed to ensure their independence, social and occupational integration and participation in the life of the community. One could argue that the Union should now ensure that its policies serve these goals.

In addition the Charter contains number of other provisions which are likely to be of particular interest to (some) disabled people. These include measures requiring respect for physical and mental integrity. This requires free and informed consent before medical treatment is provided and prohibits

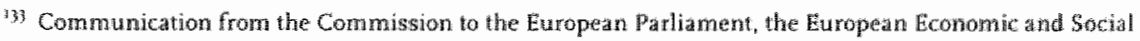
Committee and the Commitre of the Regions. situation of disabled people in the enlarged turopean Union: the European Action Plan 2006-200\%, 
eugenic practices." Other measures address rights to education, ${ }^{835}$ social security benefits and social services. ${ }^{26}$

It is also worth noting that the Commission has now adopted a mechanism to systematically screen all legislative proposals for compatibility with the EU Charter of Fundamental Rights. Key instruments in the process include impact assessments on the effect of legislation on fundamental rights and examination of legal reasoning for legislation. ${ }^{137}$

\section{Looking to the Future}

\section{A. The EU Constitution}

Intrigued by the Nice Charter, our wheelchair traveller has now been to the travel agent, and is planning her next journey. Her destination is, once again, Rome, where the new EU Constitution was signed on 29 October 2004. The Constitution has not yet been adopted; 39 - however our traveller is studying her EU guidebook to discover what changes she might encounter in the future.

The Constitution contains numerous innovations and changes, not least in the area of equality and non-discrimination. There are four main aspects of relevance to disability: the Union's values and objectives; fundamental rights: the Union's powers; and mainstreaming. ${ }^{139}$

The opening Part of the new Constitution sets out the values and objectives of the Union. Equality and non-discrimination are to be central to the activithes of the Union ${ }^{\mathrm{i} a}$ and this Part of the Treaty contains a lengthy statement of

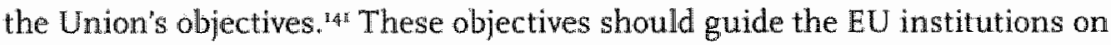
identifying the principal priorities for EU law and policy and include combating

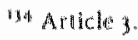

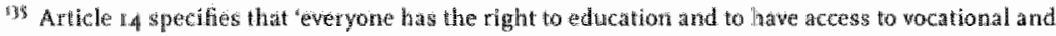
corntivumg traning".

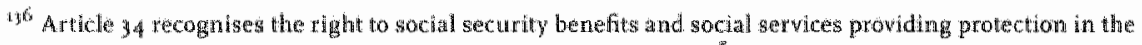
case af, amongst cthers, illness or dependency. However this provision cannot be wethed upon to enable a disabled person bo chalin specific lewel of sonidil security.

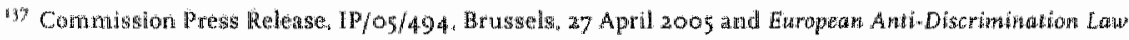
Rewisut $2(2005), 38$.

"ys Indeed. in bight of the rejection of the Constitution in the Prench and Dutch referendums in zoos, the future of the Consutution is uncertatin to say the least.

19 As noted by Mark Hell in an umpublished commentary prepared for the European Disability Forum. On file with atuthor.

${ }^{2}$ Article 1.2.

"4t Article I-y 
social exclusion and discrimination. No explicit reference to disability is made in this part of the Constitution.

The second relevant set of provisions can be found in the Charter of Funda. mental Rights. As already mentioned, the Charter has been incorporated within the Constitution and will therefore become a legally binding document if the Constitution is ratified. Although the Charter clearly contains a variety of provisions that could be useful in promoting the rights of disabled persons, it must be borne in mind that it only covers a limited number of situations. It primarily applies to the actions of the EU institutions and the Member States, but "only" when they are implementing Union law'. "4x 'There are certain actiwities that remain primarily matters of national law and where the Charter is unlikely to apply. For example, discrimination against a disabled person in the provision of healthcare does not generally fall under EU law.

Thirdly, the existing powers of the Union to combat discrimination against disabled persons found in Article 13 EC are retained in the Constitution. Disappointingly, non-discrimination remains one of the limited fields in which unanimity within the Council will still, be required for the adoption of measures.

Finally, the commitment to disability mainstreaming has been given a boost, by Article III-3, which provides: "In defining and implementing the policies and activities [...] the Union shall aim to combat discrimination based on the ground of disability, amongst others. ${ }^{\text {"I3 }}$

Existing experience with mainstreaming teaches us that the effectiveness of such a measure will depend on the machinery which is put in place to combat disability discrimination. However, this constitutional commitment to mainstreaming should greatly enhance its status.

\section{B. Combating Disability Discrimination and Promoting Equality}

It has already been roted that the $\mathrm{EC}$ has taken action to prohibit disability discrimination in the area of employment. The Framework Employment Directive allows individuals who feel that they hawe been the victims of disability discrimination to challenge an employer's behawiour before the courts. The Directive also allows organisations 'with a legitimate interest."14. to engage, either on behalf or in support of the complainant, with his or her approval, in any judicial and/or administrative procedure provided for the enforcement of obligations under this Directive' 45 However, no independent

\footnotetext{
in: Article $11-54$.

143. Article lll-3.

14: This ss to be detemined in accordance with criteria laid down by their national law".

4\% Article 9 (2). Framework Employment Directive.
} 
monitoring body is required by the Directive, and no further support is foreseen for complainants.

The system that has been established by the Directive therefore is wery muth geared to an individual complaints mechanism. This was also the case with the respect to the (original) Gender Equal Treatment Directive. of discrimination face a range of obstacles in bringing discrimination cases, amongst which financial and emotional costs are some of the most significant. The consequence is that most victims will not bring such complaints, and even when they do, it is very difficult to prove that discrimination has actually occurred. This fact means that, although the adoption of the Framework Employment Directive and national law transposing this Directive, is highly significant, and sends out an important message about the unacceptability of disability discrimination, its effect, at least in terms of case law may well be limited. This limitation is compounded by the fact that the Directive is only confined to employment-related discrimination, and many Member States have onlly taken the minimum steps necessary to transpose the Directive, and not extended protection from discrimination beyond the area of employment. The likely legal impact of the Directive, and the need for further measures, are considered below.

i. Referrals to the ECI requesting interpretations of disability provisions in the Framework Employment Directive

The coming years will see a number of preliminary references to the European Court of Justice requesting inter pretations for key provisions of the Framework Employment Directive. I hope that we will not see a series of piecemeal referrals in which the Court is called upon to determine whether particular medical conditions should result in an individual being classified as disabled, 4 and therefore entilled to rely on national disability non-discrimination legislation. We have seen both the British and the American courts having to deal with such issues, and in these jurisdictions, a high number of

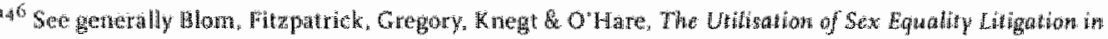

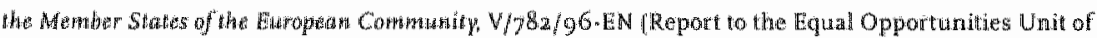
oG $\mathrm{W}$. $9 \mathrm{~g}$, especially $58-59$

wh This is the sublect of the frot distbility related preliminary reference to reach the $\mathrm{EC}$ with regard to the

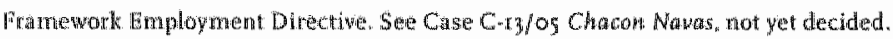

iall chis implies that Member States will have transpoged the Directive in an asymmetric manner providing protecton from distaility-based discrimination to dussabled people, but not to people who are discrimi. nated against on the grounds they do nor tave a disabiluty. The majority of Member States have indeed adopted this asymetric approach. However, the Dutch legislator has prohibited disability based discrimination for both disalbed and nor-disabled pueople (a symurnetric approach). Only the reasonable accommodation duty is exchisively directed towards disabled people under the Act on the Ecual Treatmert on Grounds of Disability or Chronic Inness.
} 
applicants have not even been given the chance to argue that they have been a victim of discrimination, because courts have denied them locus standi. Such a series of decisions would be negative development, and would not contribute to securing the goals of the Directive.

I also anticipate that we will see referrals to the Court seeking clarification of the reasonable accommodation requirement. I hope that the Court is able to respond sensitively to such referrals, and is able to understand the role which reasonable accommodation plays within non-discrimination and equality law.

\section{ii. A Disability Specific Non-Discrimination Directive}

Looking further to the future, the question of a disability specific non-discrimination directive arises. The European Disability Forum and its members have argued for some time that the Framework Employment Directive needs to be supplemented by a further Directive which would prohibit discrimi nation in other spheres, such as access to goods and services. The European Disability Forum has produced a draft Directive ${ }^{49}$ that it would like the Commission to use as the basis for a proposal. However, the Commission has made it clear that it does not feel the time is right for such a proposal. It has however commissioned a study to investigate the relevance and feasibility of possible new measures to complement the existing non-discrimination directives. It is expected that this study will be completed in autumn 2006 and, on the basis of the results, the Commission will assess the feasibility of possible new initia. tives. ${ }^{150}$

I nevertheless envisage that, in spite of the present requirement for unanimity under Article 13 , and the reluctance of the Commission to propose a further disability non-discrimination Directive, we will see the adoption of a Directive designed to combat disability discrimination with regard to access to goods and services. European legislation already prohibits such discrimination with regard to three of the grounds covered by Article 3 (race, ethric origin and sex"s"), ain increasing number of Member States already have such legislation with regard to disability, and the EU cannot reasonably maintain its inactivity in this area in the long run. Time will be needed in order to ensure the bedding down of the existing non-discrimination directives within the legal orders of the Member States, and only once the dust has begun to settle will it prove politically feasible

\footnotetext{
149 See http/fwwwedffephorg/en/polity/nondisc/nond_pub htw

150 Conmunication from the Commission to the Council, the European Partiament the European Economic and Social Committee and the Committee of the Regions. Man discrimination and equal opportumities for all - A framework strategy [SEC (2005) 689], COM (2005) 224 finall, 6 .

15: Council Directive $2004 / 113 / E C$ of 13 Decerrber 2004 iniplementing the prifteiple of equal treatment

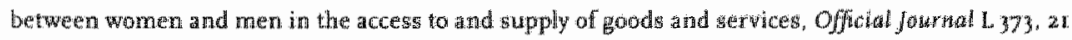
December 2004,37 .
} 
to consider further legislative non discrimination initiatives. ${ }^{55,2}$ I believe such a time will cone.

\section{iii. From Non-discrimination to 'Fourth Generation' Equality Rightits}

At the broader level, an increasing number of academics and commentators are calling for a move to what have been called "fourth generation' equality rights, at both the national and the EU level. ${ }^{15:}$ Such rights are not based on alimited prohibition of discrimination, which is enforced by individual litigation, but rather emphasise the importance of developing structural policies to promote equality and eliminate disadvantage experienced by groups. Social welfare policies, which were mentioned earlier as an important element of the European response to disability, can be brought within such an approach. As such their justification would not hie in an outdated medical model of disability, but they would rather be seen as a tool used to achieve the goal of equality.

The call for the development of positive duties to promote equality has drawn inspiration from developments in countries such as the US, Canada and the region of Northern Ireland. However, Fredman has also described the requirement to make reasonable accommodation is as 'a precursor to the positive duty to promote equality'. $\$ 4$ Positive duties go beyond an instruction not

"s a Art Hendriks has suggested an enforcement and higation strategy with regard to equal treatment law which consists of three strands: firstly, data shoulld be collected which reveals discriminatory prowisions, critenta or pratices and other obstacles disabled people encounter in their daily life, which are contrary to the primciple of equal treatment: secondly evidence should be collected showing how existing laws or policies fail to provide adequate protection against discrimination. Such shortcomings can be demonstrated by way of (a high number of complaints, and unsuccessful efforts to challenge a law or policy through a jud icial or ad ministrative procedure frnally discibility NGOs should critically assess the offects of hawg on poltcies based on the social welfore model of disability with a whew to graratee ing that these lawa or policieng contribute to equal rights and eaqual opportunines for disabled people and other disadvartaged groups. A. Hendriks, Combating Disability Discrimination after the Treaty of

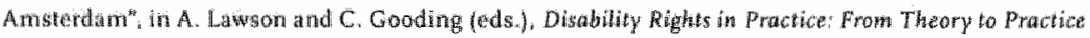
(Oxtord: Hart Pulld shing Ltd, 2005 ) 87 - 195 .

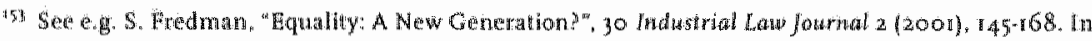
the context of disablity this approach is (briefly) referred to in D. Mabbett. "Some are more equal than others: Defintions of disability an social policy and discrimination law in Europe" avallable at: hetp:

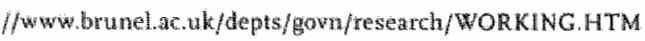

"5a sandra Fredman. "Disability Equality, A Challenge to the Existing Anti-Discrimination Pandigme" in A. Lawson and C. Gooding (eds.). Disability Rights in Practice: From Theory to Practice (Oxford: Hart Publishing (tdd, zoogi 199 a zr. However. Fredman also notes that, in some respects, the reasonable atcommodation requirement ig more limited than the positive duty found in fourth-generation equality statutes. This is because of its individualist perspective and its fallue to address grounds other than disability (in the context of UK lawi). 
to discriminate or the creation of room for positive action, but instead impose duties on employers (and perhaps other distributors of social goods) to promote equality and diversity. This duty is not driven by indiwidual complainants, nor is it confined to individual discriminators. Instead, the assumption is that; in order to address the structural nature of discrimination and disadvantage, all employers (above a certain size) should be obliged to undertake action to promote equality. The origin of this duty lies in the pragmatic assessment that those best able to take effective action - namely employers in the case of employment related discrimination and disadvantage - should be obliged to do so. The imposition of the duty is therefore not based on any attribution of fault, and is proactive rather than reactive.

Such duties usually involve some form of (self) monitoring of the workforce, the development of an employment equity plan, and the taking of remedial action where this monitoring reveals an under-representation of women or minority groups. Employers can be required to adopt best practices, such as publicly advertising all vacancies (rather than recruiting via word of mouth, which would tend to reproduce the existing composition of the workforce). explicitly including equality and diwersity matters within personnel policy and conferring responsibilities for coordinating this policy on a member of staff, and adopting a family friendly employment policy. Where, in spite of such practices, monitoring reveals an under representation of a particular group in the work force, employers can be obliged to adopt positive action targeted at that group. Usually some forms of external inspections and monitoring will be required to ensure that employers comply with these obligations, along side a set of guidelines to assist employers in meeting their obligations. The results of the selfmonitoring exercise can provide information on which to base decistons to investigate, as can complaints from individuals and/or trade unions. Experience from the US with regard to employment equity suggests that an institution ${ }^{\text {'s }}$ which only has the capacity to inwestigate a limited number of employers, sut which targets its actions on the basis of employer reports and complaints, and which has the power to require change and impose penalties, can have a signifi. cant effect. Finally, interest groups should also be involved with the regullated parties, which should be required to inform, consult and engage with such groups. ${ }^{g \circ 6}$

Positive duties to promote equality can also be imposed through a contract compliance programme or employment equity programme, whereby undertakings contracting with the public authorities, or tendering for such bids, are

Is5 whe Office of Federal Contract Cortupliance Programs. See B. Hepple. M. Coussey and

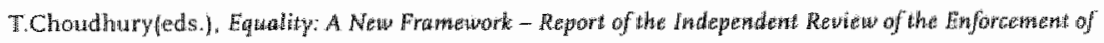

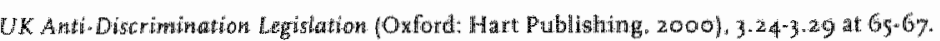

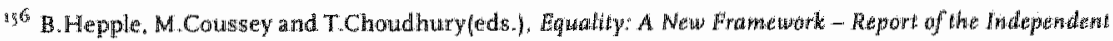

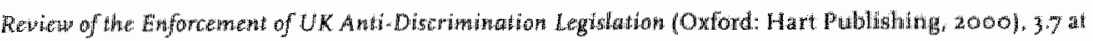
58. 
obliged to have undertaken certain steps to promote equality. ${ }^{57}$ In addition to admission to tenders, similar requirements could be attached to applications for, or the award of, grants, subsidies, licences and franchises. These requirements can likewise be the subject of (self-y montoring and reporting, and a compliance and enforcement system managed "by an independent body which can ultimately order the withdrawal of public contracts or publicly awarded benefits.

Finally, positive duties should promote participation and social inclusion. This covers mot only participation in the workforce, but all aspects of social and economic life, including participation in decision-making. The participation of disabled people, and other marginalized groups, will increase the chances of policies meeting the set goals as well as meeting democratic requirements. Mainstreaming of disability issues in general policies is one element that can be used to achieve this goal, but full participation extends much more widely than this.

This issue is clearly not only of relevance to disabled people, but to all indiwiduals and groups covered by Conmunity equality law. A revisiting of EC equality law, leading to a move towards such 'fourth generation' rights (which admittedly seems highly unlikely in the immediate future) could hold out the promise of substantial changes in the way employers and other parties respond to disability, and would most likely reap far greater advantages than the limited non-discrimination approach, albeit an approach which recognises the need to accommodate disabled workers.

\section{iv. A United Nations Convention on the Rights of Disabled People}

At the international level, a United Nations Convention on the rights of disabled people is currently being negotiated. 158 "This Convention once $^{-}$ adopted, will have the same status as the Convention on the Elimination of Discrimination Against Women and the Convention on the Elimination of Racial Discrimination. Both the Member States and the European Commission ${ }^{\text {is }}$ are

8\% Bob thepple, Mary Codsaty and Tufyal Choudhury identify five main strategres of regulation to promote equality rightes and liabitaties, based on the $x$ ight of indiwiduals to bring claims; cornmand and control. whereby an independent public agency sets standards and enforces them through investigations and court actons; whtury self regulation. Whereby onganisations comply with prestribed standards

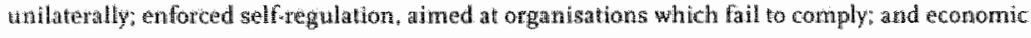
incentues to encourage conpliances stich as the award of public contracts. B. Hepple. M.Coussey and

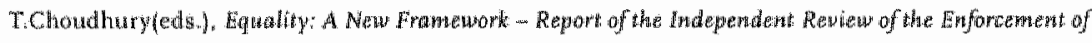
UK Anti-Discrimation Legislation (Oxford: Hart Publishing, 3000 ). 3.2 at 56.

ig For futher information see G. Quinu. "Closing: Next Steps - Towards a United Mation's Treary on the kights of Persons with Disabillities", in Blanck (ed.). Disabulhy Rights, The International Library of Lssays on Rights (London: Ashgate, 2005 ) 519 .

${ }^{3} 9$ See Commission Communication "Towards anited Nations legally binding instrument to promote and protect the rights and dignity of persons with disabilities". COM (2003) 16 final 24 laruary 2003. 
involved in the negotiation of the Convention, as is the European Disability Forum.

\section{Conclusion}

The original involvement of the Community in the area of disability policy was highly limited and restricted by the absence of clear Community competences in the Treaty. As a consequence, the Action Programmes of the 1970 and 1980 s were non-binding initiatives that focussed primarily on information exchange and dissemination and networking, and they bear little resemblance to the current disability action plan with its focus on enforcing legisllative initiatives, wide-ranging disability policy and mainstreaming. The legal breakthrough with regard to disability came with Article 3 EC, incorporated by means of the Amsterdam Treaty, which gave the Community the competence to address disability discrimination, as well as amounting to the first reference to disability in the Treaty. "This had been preceded in 1996 by a philosophical breakthrough, with both the Commission and the Council embracing the social model of disability and committing themselves to the mainstreaming of disability issues. This step also opened the door to a more active involvement of organisations made up of disabled people, such as the European Disability Forum.

The Community utilised this new legislative competence in 2000 to adopt the Framework Employment Directive, which prohibits employment related discrimination on the grounds of disability and requires the making of reasonable accommodations for disabled individuals. This Directive has been the main legislative achievement with regard to cisability policy thus far. lt has clearly already had a major impact on rational legislation throughout the $\mathrm{EU}$, and case law, which will hopefully elaborate and clarify the provisions of the Directive, whilst also providing a sensitive and expansive interpretation of the key provisions, will steadily stream out from the European Court of Justice in the coming years. In contrast, narrow and limited inter pretations of the Directive from the ECJ will significantly reduce its effectiveness and impact. The future challenge for the EU will be to develop both broader disability non-discrimination legis. lation in areas beyond employment, as well as promoting the development of 'fourth generation' proactive equality rights with regand to disability and other grounds currently covered by non-discrimination directives.

European disability law and policy is an area of growing importance. If developed and expanded, it has the potential to lead to improvements in the lives of some of the most disadvantaged EU citizens and residents - however, to achieve such success will require a deep commitment on the part of the EU institu. tions and Member States. Both disability specific initiatives, such as a Goods and Service non-discrimination Directive, and wide-ranging and thorough mainstreaming of disability issues will be required. The challenge is great, and will only be successfully responded to if representatives of disabled people are regarded as partners in the process. 
